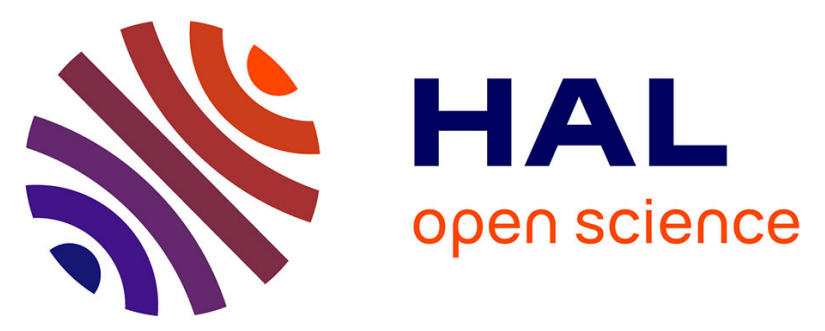

\title{
In vitro study of carbon black nanoparticles on human pulmonary artery endothelial cells: effects on calcium signaling and mitochondrial alterations
}

Juliette Deweirdt, Jean-François Quignard, Sabrina Lacomme, Etienne Gontier, Stéphane Mornet, Jean-Pierre Savineau, Roger Marthan, Christelle Guibert, Isabelle Baudrimont

\section{To cite this version:}

Juliette Deweirdt, Jean-François Quignard, Sabrina Lacomme, Etienne Gontier, Stéphane Mornet, et al.. In vitro study of carbon black nanoparticles on human pulmonary artery endothelial cells: effects on calcium signaling and mitochondrial alterations. Archives of Toxicology, 2020, 94 (7), pp.2331-2348. 10.1007/s00204-020-02764-9 . hal-02885389

\section{HAL Id: hal-02885389 https://hal.science/hal-02885389}

Submitted on 6 Jul 2020

HAL is a multi-disciplinary open access archive for the deposit and dissemination of scientific research documents, whether they are published or not. The documents may come from teaching and research institutions in France or abroad, or from public or private research centers.
L'archive ouverte pluridisciplinaire HAL, est destinée au dépôt et à la diffusion de documents scientifiques de niveau recherche, publiés ou non, émanant des établissements d'enseignement et de recherche français ou étrangers, des laboratoires publics ou privés. 


\title{
In vitro study of carbon black nanoparticles on human pulmonary artery endothelial cells: effects on calcium signaling and mitochondrial alterations
}

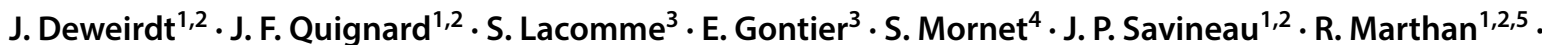 \\ C. Guibert ${ }^{2} \cdot$ I. Baudrimont $^{1,2}$ (1)
}

Received: 7 January 2020 / Accepted: 22 April 2020

(c) Springer-Verlag GmbH Germany, part of Springer Nature 2020

\begin{abstract}
Human exposure to manufactured nanoparticles (NPs) is a public health concern. Endothelial cells lining the inner surface of arteries could be one of the primary targets for inhaled nanoparticles. Moreover, it is well known that alteration in calcium signaling is a critical event involved in the physiopathology of cardiovascular diseases. The objective of this study was to assess the role of oxidative stress in carbon black FW2 NPs-induced alteration in calcium signaling and mitochondria in human pulmonary artery endothelial cells. To this end, cells were exposed for 4 or $24 \mathrm{~h}$ to FW2 NPs $\left(1-10 \mu \mathrm{g} / \mathrm{cm}^{2}\right)$ and the following endpoints were studied: (i) production of ROS by fluorimetry and electron paramagnetic resonance, (ii) variation in intracellular calcium concentration by confocal microscopy, and (iii) mitochondrial alteration and apoptosis by confocal microscopy and transmission electronic microscopy. Exposure to FW2 NPs concentration-dependently increases oxidative stress, evidenced by the production of superoxide anion leading to an alteration in calcium content of intracellular organelles, such as endoplasmic reticulum and mitochondria activating, in turn, intrinsic apoptosis. This study provides evidence that FW2 NPs exposure impairs calcium signaling and mitochondria triggered by oxidative stress, and, thus, could act as a cardiovascular disease risk owing to the key role of calcium homeostasis in the control of vascular tone.
\end{abstract}

Keywords Carbon black nanoparticles · Pulmonary endothelial cells $\cdot$ Reactive oxygen species $\cdot$ Calcium imaging · Mitochondrial dysfunction · Apoptosis

I. Baudrimont

isabelle.baudrimont@u-bordeaux.fr

J. Deweirdt

juliette.deweirdt@u-bordeaux.fr

J. F. Quignard

jean-francois.quignard@u-bordeaux.fr

S. Lacomme

sabrina.lacomme@u-bordeaux.fr

E. Gontier

etienne.gontier@u-bordeaux.fr

S. Mornet

stephane.mornet@u-bordeaux.fr

J. P. Savineau

jean-pierre.savineau@u-bordeaux.fr

R. Marthan

roger.marthan@u-bordeaux.fr

\section{Guibert}

christelle.guibert@u-bordeaux.fr

1 Univ. Bordeaux, Centre de Recherche Cardio-Thoracique de Bordeaux U 1045, 33604 Pessac, France

2 Inserm, Centre de Recherche Cardio-Thoracique de Bordeaux U1045, 33600 Pessac, France

3 CNRS, Bordeaux Imaging Center UMS 3420 CNRS-US4 INSERM, 33000 Bordeaux, France

4 CNRS, Univ. Bordeaux, Bordeaux INP, ICMCB, UMR 5026, 33076 Bordeaux, France

5 CHU de Bordeaux, Service d'Exploration Fonctionnelle Respiratoire, 33000 Bordeaux, France 


\section{Background}

Nowadays, current development and use of nanotechnologies increase the production of engineered nanomaterials, including nanoparticles (NPs). As a consequence, health risks of human exposure are also increasing, especially for workers and consumers (Schulte et al. 2009; Bergamaschi et al. 2015). A large variety of NPs are produced, in huge quantities, worldwide, such as titanium dioxide, carbon black, alumina, multi-walled carbon nanotubes (MWCNT), amorphous silica, iron oxide, etc. (Borm et al. 2006; Wu and Tang 2018). Carbon black NPs, mainly composed of elementary carbon, are potentially more harmful than larger-sized particles because of their high surface reactivity, physical properties and large surface area leading to greater interactions with biological systems (Monteiller et al. 2007; Hussain et al. 2009). There are differences between manufactured carbon black NPs and unwanted soot NPs produced by incomplete hydrocarbons combustion processes. Purity and capacity of aggregation are higher in carbon black NPs as compared to soot NPs (Watson and Valberg 2001). This study, thus, focuses on the effect of manufactured carbon black NPs owing to their large variety of applications (rubber, pigment industry, bicycle and drone manufacturing...) and, hence, their risk of causing human exposure (Boland et al. 2014). After inhalation, the deposition of NPs into the lung is greater than that of larger-sized particles, and the former may accumulate into pulmonary alveoli and lung parenchyma, close to pulmonary arteries. NPs also cross more efficiently the pulmonary epithelial barrier to reach the pulmonary circulation where they can be in direct contact with endothelial cells (EC) lining the inner surface of arteries (Nemmar et al. 2002). EC play a key role in the physiology of the pulmonary circulation and regulate vascular function (Goldenberg and Kuebler 2015). These cells are involved in different biological processes to adapt vascular tone, to control coagulation and vascular barrier integrity and to maintain intracellular calcium homeostasis (Vanhoutte et al. 2017). It has been reported that endothelial injury is a critical mechanism by which inhaled NPs induce vascular diseases (Miller et al. 2017). Various experimental studies have related exposure to nano-sized carbon black particles to cardiovascular diseases (Mossman et al. 2007) including cardiac arrhythmia (Yamawaki and Iwai 2006), atherosclerosis (Niwa et al. 2007), cardiac cell damages (Helfenstein et al. 2008) and vascular reactivity alterations (Vesterdal et al. 2010). It is well known that oxidative stress and alteration in calcium signaling are critical events involved in the physiopathology of cardiovascular diseases (Guibert et al. 2007; Lai et al. 2015). The cross-talk between oxidative stress and calcium signaling can be considered as bidirectional, since reactive oxygen species (ROS) regulate intracellular calcium signaling; whereas, calcium signaling also regulates ROS production (Gordeeva et al. 2003). Impairment in ROS production might play a role in calcium signaling and can alter cell homeostasis (Touyz 2005). Moreover, some studies have reported, in various human cell types (epithelial cells, monocytes, macrophages and umbilical vein endothelial cells), that nano-sized carbon black particles trigger oxidative stress with overproduction of ROS associated with a pro-inflammatory response leading to an endothelial dysfunction (Calderon-Garciduenas et al. 2001; Vesterdal et al. 2010, 2012; Cao et al. 2014; Yan et al. 2017). A study by Brown et al. (2010) has also reported an alteration in calcium $\left(\mathrm{Ca}^{2+}\right)$ homeostasis in A549 epithelial cells and macrophages after exposure to carbon black NPs. Nevertheless, the link between ROS production and $\mathrm{Ca}^{2+}$ signaling has not yet been reported after carbon black NPs exposure. Endothelial dysfunction is thus believed to contribute to cardiovascular diseases, and is often associated with ROS production as well as calcium signaling and mitochondrial impairment (Davidson and Duchen 2007). An alternative origin of ROS production is the mitochondrion, which also plays a key role in calcium homeostasis, cell proliferation and apoptosis (Quintero et al. 2006). Therefore, mitochondria are potential target organelles for NPs-induced toxic effects (Shen et al. 2018) along with other organelles such as endoplasmic reticulum (ER) (Zhang et al. 2012; Simon et al. 2017). However, despite the major role of endothelial dysfunction in the pathogenesis of vascular disease, the underlying mechanisms and cellular and molecular pathways by which engineered carbon black NPs alter calcium signaling in human pulmonary vascular cells have not yet been reported. Thus, because of the potential increase in human exposure to carbon black NPs, it is crucial to evaluate their toxic effects for risk assessment of workers and consumers. In this context, the objectives of the present study were to assess in human pulmonary artery endothelial cells (HPAEC): (i) the effect of FW2 NPs exposure on calcium signaling, mitochondria and apoptosis; and (ii) the role of oxidative stress on this effect. Different endpoints were studied such as: (i) intracellular ROS production; (ii) intracellular calcium signaling; (iii) mitochondrial damages and (iv) apoptosis.

\section{Methods}

\section{Reagents and chemicals}

The standard physiological salt solution (PSS) was composed of: 130-mM NaCl, 5.6-mM KCl, 8-mM HEPES, 
11-mM Glucose, 1-mM $\mathrm{Mg}^{2+}$ and 2-mM Ca ${ }^{2+}$, adjusted at $\mathrm{pH}=7.4$ with $\mathrm{NaOH}$. All the fluorescent probes were obtained from ThermoFischer Scientific, Invitrogen ${ }^{\mathrm{TM}}$ (Illkirch, France), except Rhod-2, AM red dye which was obtained from Euromedex (Souffelweyersheim, France). All the probes were diluted in DMSO. All of the following chemical reagents were purchased from Sigma-Aldrich (StQuentin-Fallavier, France) and used as follows: 1,2-bis(oaminophenoxy)ethane- $N, N, N^{\prime}, N^{\prime}$-tetraacetic acid (BAPTA$\mathrm{AM})$ as a specific calcium intracellular chelator, diluted in culture medium $(5 \mu \mathrm{M})$; adenosine triphosphate (ATP) as an activator of the phospholipase $\mathrm{C}$ beta/Inositol triphosphate pathway which induces $\mathrm{Ca}^{2+}$ release from the ER to cytosol, diluted in PSS (20 $\mu \mathrm{M})$; carbonyl cyanide 3-chlorophenylhydrazone (CCCP) as a mitochondrial fission inductor, diluted in culture medium $(5 \mu \mathrm{M})$; ethylene glycol-bis $(\beta$-aminoethyl ether)- $N, N, N, N$-tetraacetic acid (EGTA) as a chelator of extracellular calcium, diluted in culture medium $(5 \mathrm{mM})$; thapsigargin as a non-competitive inhibitor of the sarco/ endoplasmic reticulum $\mathrm{Ca}^{2+}$ ATPase, diluted in PSS $(1 \mu \mathrm{M})$; superoxide dismutase-polyethylene glycol (PEG-SOD) and catalase-polyethylene glycol (PEG-CAT) as antioxidants enzymes, diluted in culture medium $(300 \mathrm{U} / \mathrm{mL}$ and $600 \mathrm{U} /$ $\mathrm{mL}$, respectively).

\section{NPs characterization}

Carbon black nanoparticles (FW2 NPs) were acquired from Degussa (Evonik Industries, Essen, Germany). FW2 NPs physical and chemical properties have been previously described by L'Azou et al. (2008). These consist in elemental amorphous carbon and have the following characteristics: a mean aerodynamic diameter of $13 \mathrm{~nm}$, surface area of $350 \mathrm{~m}^{2} / \mathrm{g}$ and $\mathrm{pH}=2.5$. FW2 NPs were suspended in Endothelial Cell Growth Medium (ECGM) at a final concentration of $2 \mathrm{mg} / \mathrm{mL}$ and stored at $4{ }^{\circ} \mathrm{C}$ until use. Immediately prior use, stock suspensions were vortexed, sonicated at $3 \times 30 \mathrm{~s}$ (Vibracell 75186, $130 \mathrm{~W}, 56-60 \mathrm{~Hz}$ ), and freshly diluted at appropriate concentrations (1-10 $\mu \mathrm{g} /$ $\mathrm{cm}^{2}$ ) in ECGM.

\section{FW2 NPs hydrodynamic size in endothelial cell growth medium}

The hydrodynamic size of FW2 NPs at two concentrations (5 and $10 \mu \mathrm{g} / \mathrm{cm}^{2}$ ) in ECGM was assessed using a VASCO particle size analyzer from Cordouan Technologies. Both samples were sonicated on an ultrasonic bath for $5 \mathrm{~min}$ before measurements. Then, a volume of $800 \mu \mathrm{L}$ of the dilute particle solution was dropped off onto the measurement cell. The laser diode intensity of $658 \mathrm{~nm}$ was adjusted and the sample was cooled to a temperature of $20^{\circ} \mathrm{C}$. The value of refractive index and viscosity of the solvent, i.e., 1.331 and $0.888 \mathrm{cP}$, as well as that of the refractive index of the carbon black particles $(m=2-1.0 i)$ (Janzen 1979) were entered into the NanoQ software which then controlled the subsequent measurements. A real-time signal was measured; acquisitions were implemented every $30 \mathrm{~s}$ if the noise of the signal did not exceed $1.06 \%$, and 8 acquisitions were accomplished during $16 \mathrm{~min}$. Size distributions of the nanoparticles in ECGM were analyzed by Sparse Bayesian Learning (SBL) algorithm, dedicated to multimodal distribution size analysis, provided by NanoQ software.

\section{Cell culture}

HPAEC human pulmonary endothelial cells were isolated from pulmonary artery main branch of a 23 -year-old male Caucasian donor. HPAEC were acquired from PromoCell ${ }^{\circledR}$ (Heidelberg, Germany), and cultured in ECGM (with phenol red) supplemented with a Supplement Mix [2\% fetal bovine serum (FBS), $0.4 \%$ endothelial cell growth factor (ECGF), $0.1 \mathrm{ng} / \mathrm{mL}$ epidermal growth factor (EGF), $1 \mathrm{ng} /$ $\mathrm{mL}$ basic fibroblast growth factor (BFGF), $90 \mu \mathrm{g} / \mathrm{mL}$ heparin, and $1 \mu \mathrm{g} / \mathrm{mL}$ hydrocortisone, PromoCell $\left.{ }^{\circledR}\right]$ in humidified atmosphere with $5 \% \mathrm{CO}_{2}$ at $37{ }^{\circ} \mathrm{C}$. All experiments were done on HPAEC from passages 2 to 8 .

\section{Cytotoxicity assay}

Cell viability was assessed using the WST-1 (Water Soluble Tetrazolium) cell proliferation reagent (Roche, France), according to the manufacturer's recommendations. Cells were seeded in a 96-well culture plate, at 20,000 cells $/ \mathrm{cm}^{2}$ for $24 \mathrm{~h}$. Cells were then exposed to $1-10 \mu \mathrm{g} / \mathrm{cm}^{2} \mathrm{FW} 2 \mathrm{NPs}$ for $24 \mathrm{~h}$, at $37^{\circ} \mathrm{C}$ and $5 \% \mathrm{CO}_{2}$. Following exposure, $20 \mu \mathrm{L}$ of WST-1 reagent was added to the wells for $3 \mathrm{~h}$. The absorbance was measured at $450 \mathrm{~nm}$ by spectrophotometry using a microplate spectrophotometer reader (SPECTROstarNano2.10, BMG Labtech ${ }^{\circledR}$, Germany). The working concentrations for all further experiments were determined by this test (mortality rate less than $25 \%$ ).

\section{Global reactive oxygen species production}

Intracellular ROS production was measured using the CM$\mathrm{H}_{2}$ DCFDA probe (Fisher Scientific ${ }^{\circledR}$ ), according to the manufacturer's recommendations and using the method adapted from previous studies (Wang and Joseph 1999; Chen et al. 2010). HPAEC cells were seeded at 50,000 cells $/ \mathrm{cm}^{2}$ in a 24-well plate and cultured for $24 \mathrm{~h}$, at $37{ }^{\circ} \mathrm{C}$ and $5 \%$ $\mathrm{CO}_{2}$. Cells were rinsed with Hank's Balanced Salt Solution (HBSS), and were pre-incubated for 20 min with CM$\mathrm{H}_{2}$ DCFDA probe (final concentration $20 \mu \mathrm{M}$ ) in HBSS. Cells were then rinsed with HBSS before a 4-h exposure with FW2 NPs, at different concentrations $\left(5-10 \mu \mathrm{g} / \mathrm{cm}^{2}\right)$ at 
$37^{\circ} \mathrm{C}$. Fluorescence intensity was measured at $\lambda_{\mathrm{ex}}=485 \mathrm{~nm}$ and $\lambda_{\mathrm{em}}=520 \mathrm{~nm}$ with spectrofluorimetry using FLUOstar Omega 2.10 plate reader, and the analyses were performed with the MARS Data Analysis Software 2.30 R3 (BMG Labtech $^{\circledR}$ ).

\section{Superoxide anion detection by electron paramagnetic resonance (EPR)-spin trapping}

EPR assay was performed as previously described (Billaud et al. 2009; Deweirdt et al. 2017). HPAEC cells were seeded at 50,000 cells $/ \mathrm{cm}^{2}$ in a 12-well plate and cultured for $24 \mathrm{~h}$, at $37^{\circ} \mathrm{C}$ and $5 \% \mathrm{CO}_{2}$. After a 4-h exposure with FW2 NPs at different concentrations $\left(5-10 \mu \mathrm{g} / \mathrm{cm}^{2}\right)$, at $37{ }^{\circ} \mathrm{C}$ and $5 \% \mathrm{CO}_{2}$, cells were incubated for $20 \mathrm{~min}$ with the spinprobe mix containing $\mathrm{CMH}(1 \mathrm{mM})$, diethyldithiocarbamate $(5 \mu \mathrm{M})$ and deferoxamine $(25 \mu \mathrm{M})$ in Krebs-HEPES Buffer solution. Then, cells were scraped, homogenized and frozen in a syringe in liquid nitrogen before EPR analysis. All EPR spectra were recorded using a Spectrometer X Miniscope MS200 (Magnettech ${ }^{\circledR}$, Berlin, Germany). After reading of EPR spectra, protein quantities were measured by Lowrytest (Lowry reagent, Sigma Aldrich), according to the manufacturer's recommendations. The results were normalized to protein quantities and expressed in EPR signal amplitude, in arbitrary units $(\mathrm{AU}) / \mathrm{mg} / \mathrm{mL}$ of protein.

\section{Cytosolic calcium measurement by confocal microscopy}

Variation in intracellular cytosolic calcium $\left[\mathrm{Ca}^{2+}\right]_{\mathrm{i}}$ was detected using the Fluo-4, AM green dye (1-[2-amino5-(2,7-difluoro-6-hydroxy-3-oxo-9-xanthenyl)phenoxyl]2-(2-amino-5-methylphenoxy) ethane- $N, N, N, N$-tetraacetic acid, pentaacetoxymethyl ester) (ThermoFischer ${ }^{\circledR}$ ), according to the manufacturer's recommendations. HPAEC cells were seeded at 20,000 cells $/ \mathrm{cm}^{2}$ in a 96-well plate and cultured for $24 \mathrm{~h}$, at $37{ }^{\circ} \mathrm{C}$ and $5 \% \mathrm{CO}_{2}$. Then, HPAEC were exposed to the FW2 NPs suspension $\left(5-10 \mu \mathrm{g} / \mathrm{cm}^{2}\right)$ for $4 \mathrm{~h}$. After, cells were incubated for $30 \mathrm{~min}$ (in the dark, at $37{ }^{\circ} \mathrm{C}$ ) with $1 \mu \mathrm{M}$ Fluo- 4 , AM probe in the PSS. At last, to measure the acute responses to ATP and thapsigargin, cells were rinsed with the PSS and $100 \mu \mathrm{L}$ of this solution was added in each well. In some experiments, Fluo-4, AM probe was co-incubated with a nucleus probe (Hoeschst 33342, at final concentration of $2 \mu \mathrm{M}$ ). The plates were observed at X200 magnification with an oil immersion objective on a laser scanning confocal microscope (TE 2000, Nikon). Fluorescence intensity was measured for Fluo-4, AM at $488 / 515 \mathrm{~nm}$, and for Hoeschst at 408/450 nm. Analyses were performed using NIS-Elements AR software 3.0, and Microsoft Office Excel 2007.

\section{Endoplasmic reticulum calcium measurement by confocal microscopy}

ER calcium $\left[\mathrm{Ca}^{2+}\right]$ was detected, as above described, using the Fluo-4FF, AM green dye at $10 \mu \mathrm{M}$ (ThermoFischer ${ }^{\circledR}$ ). Cells were incubated for $30 \mathrm{~min}$ (in the dark, at $37^{\circ} \mathrm{C}$ ) with $10-\mu \mathrm{M}$ Fluo-4FF, AM probe in the PSS. In some experiments, Fluo-4FF, AM probe was co-incubated with an ER specific probe (ER-tracker, at final concentration of $2 \mu \mathrm{M}$ ) for colocalization experiments. Fluorescence intensity was measured at $488 / 515 \mathrm{~nm}$, and for ER-tracker at $408 / 450 \mathrm{~nm}$ (excitation/emission).

\section{Mitochondrial calcium measurement by confocal microscopy}

Mitochondrial calcium $\left[\mathrm{Ca}^{2+}\right]_{\mathrm{m}}$ was assessed, as above described, using Rhod-2, AM red dye (Euromedex), according to the manufacturer's recommendations. Cells were incubated for $30 \mathrm{~min}$ (in the dark, at $37^{\circ} \mathrm{C}$ ) with $1 \mu \mathrm{M}$ Rhod-2, $\mathrm{AM}$ probe in the PSS. Fluorescence intensity was measured at $543 / 605 \mathrm{~nm}$.

\section{Mitochondrial superoxide anion production by confocal microscopy}

Mitochondrial superoxide anion $\mathrm{O}_{2}^{-}$formation was assessed, as above described, using MitoSOX ${ }^{\mathrm{TM}}$ red dye (ThermoFischer ${ }^{\circledR}$ ) according to the manufacturer's recommendations. Cells were incubated for 10 min (in the dark, at $37^{\circ} \mathrm{C}$ ) with $5-\mu \mathrm{M}$ MitoSOX ${ }^{\mathrm{TM}}$ probe in the PSS. In some experiments, MitoSOX ${ }^{\mathrm{TM}}$ probe was co-incubated with a mitochondrial probe (Mitotracker green, at final concentration of $1 \mu \mathrm{M}$ ) for colocalization experiments. Fluorescence intensity was measured for MitoSOX at 543/605 nm, and for Mitotracker at 488/515 nm.

\section{Mitochondrial membrane potential measurement by confocal microscopy}

Mitochondrial membrane potential (YMP) was measured, as above described, by TMRM red dye (Tetramethylrhodamine, Methyl Ester, Perchlorate) (ThermoFischer ${ }^{\circledR}$ ), according to the manufacturer's recommendations. Cells were incubated for $20 \mathrm{~min}$ (in the dark, at $37{ }^{\circ} \mathrm{C}$ ) with 100-nM TMRM probe in the PSS. Fluorescence intensity was measured at $543 / 605 \mathrm{~nm}$.

\section{NPs internalization studies}

Cells were seeded at 20,000 cells $/ \mathrm{cm}^{2}$ on plastic Lab-Tek chambers (Dutscher, France), and cultured in supplemented ECGM for $24 \mathrm{~h}$, at $37{ }^{\circ} \mathrm{C}$ and $5 \% \mathrm{CO}_{2}$. Cells were then 
exposed or not (control cells) to FW2 NPs at $7.5 \mu \mathrm{g} / \mathrm{cm}^{2}$, for $1 \mathrm{~h}$ at $37{ }^{\circ} \mathrm{C}$ and $5 \% \mathrm{CO}_{2}$. Finally, cells were fixed with $1.6 \%$ paraformaldehyde and $2 \%$ glutaraldehyde in $0.08-\mathrm{M}$ cacodylate buffer ( $\mathrm{pH}$ 7.4) during $2 \mathrm{~h}$, at room temperature (RT). After washing in $0.1 \mathrm{M}$ cacodylate buffer, cells were post-fixed in a mix $1 \%$ osmium tetroxide $(\mathrm{v} / \mathrm{v}) / 1 \%$ potassium ferricyanide $\mathrm{K}_{3} \mathrm{Fe}(\mathrm{CN})_{6}(\mathrm{p} / \mathrm{v})$ in the same cacodylate buffer, during $2 \mathrm{~h}$ on ice in the dark. Then, samples were washed in pure water (RiOs-DI type II water purification system (resistivity $>10 \mathrm{M} \Omega \mathrm{cm}$ ), and stained in block in $0.5 \%$ aqueous uranyl acetate solution during $30 \mathrm{~min}$, at RT in the dark. Subsequently, cells were washed and dehydrated through a series of graded ethanol, and embedded in a mixture of pure ethanol and epoxy resin 50/50 (v/v) (Epon 812; Delta Microscopie, Toulouse, France) during 2 h, and then in $100 \%$ resin overnight at RT. The polymerization of the resin was carried out during $48 \mathrm{~h}$ at $60{ }^{\circ} \mathrm{C}$. Samples were then sectioned using a diamond knife (Diatome, BielBienne, Switzerland) on an ultramicrotome (EM UCT, Leica Microsystems, Vienna, Austria). Ultrathin sections (65 nm) were picked up on copper grids, and then stained with Uranyless (Delta Microscopies, Toulouse, France) and lead citrate. Grids were examined with a Transmission Electron Microscope (H7650, Hitachi, Tokyo, Japan), at $80 \mathrm{kV}$.

\section{Mitochondrial dynamic imaging}

Mitochondrial dynamic was assessed, as above described, using Mitotracker green dye (ThermoFischer ${ }^{\circledR}$ ), according to the manufacturer's recommendations. Cells were incubated for $30 \mathrm{~min}$ (in the dark, at $37{ }^{\circ} \mathrm{C}$ ) with $1-\mu \mathrm{M}$ Mitotracker probe in the PSS, co-incubated with a nucleus probe (Hoeschst 33342, at final concentration of $2 \mu \mathrm{M}$ ). Fluorescence intensity was measured for Mitotracker at 488/515 nm and for Hoeschst at 408/450 nm (excitation/emission).

\section{Apoptosis induction}

Apoptosis induction was assessed, as above described, using FAM-FLICA ${ }^{\circledR}$ Caspase 9 Assay Kit (EnzoLifeScience ${ }^{\circledR}$ ), according to the manufacturer's recommendations. Cells were incubated for $30 \mathrm{~min}$ (in the dark, at $37^{\circ} \mathrm{C}$ ) with $30 \times$ Flica into aqueous buffers. The plates were observed at $600 \times$ magnification. Fluorescence intensity was measured for Caspase- 9 probe at $488 / 610 \mathrm{~nm}$, and for Hoeschst at $408 / 450 \mathrm{~nm}$ (excitation/emission).

\section{Statistical analysis}

Each experimental condition was independently repeated three times, and for each independent experiment, 3-8 replicates (wells) per condition were tested. Data are expressed as mean \pm standard error of the mean (SEM), for three independent experiments $(n=3)$. Statistical analyses were performed using one-way ANOVA with Tukey's post-test for multiple comparisons $(n>30)$, and by Kruskal-Wallis test with Dunn's post-test $(n<30)(* P$ value $<0.05 ; * * P$ value $<0.01 ; * * * P$ value $<0.001)$ using GraphPad statistics software. $P$ values $<0.05$ were considered significant.

\section{Results}

\section{FW2 NPs hydrodynamic size in endothelial cell growth medium}

Dynamic light scattering measurement (DLS) was implemented to assess the colloidal stability state of carbon black NPs in the cell culture growth medium. The results show that FW2 NPs flocculate immediately after dispersion in Endothelial Cell Growth Medium (ECGM). For this reason, FW2 NPs were sonicated just before the measurements. The size distribution data were analyzed using a probabilistic self-learning algorithm, so-called Sparse Bayesian Learning (SBL) adapted for very poly-dispersed particle suspensions to improve the resolution of multimodal size distributions. Both samples displayed quite the same results whatever their concentrations ( 5 or $10 \mu \mathrm{g} / \mathrm{cm}^{2}$ ) with two peaks detected around $130 \pm 20 \mathrm{~nm}$ and $525 \pm 40 \mathrm{~nm}$, showing the flocculation state of FW2 NPs of 13-nm unit size (Fig. 1a). The two distribution peaks can be explained by the effect of sonication on large aggregates formed after addition of the FW2 NPs in the culture medium and, eventually, by the stabilization of nanoparticle clusters by serum proteins. These results show hydrodynamic sizes weighted in intensity of scattering signal, and do not represent the distribution in number of all sizes of the nanoparticle aggregates. For this reason, the Mie correction was apply to convert scattered intensity to relative particle numbers (Fig. 1b). After this numerical correction, the first peak corresponded to aggregates of $130 \mathrm{~nm}$ representing $86 \%$ in number; whereas, the second of $525 \mathrm{~nm}$ represented only $14 \%$ of the overall number of aggregates.

\section{FW2 NPs decrease HPAEC viability}

To understand the mechanism of FW2 NPs-induced effect in HPAEC, the non-toxic range of FW2 NPs concentration (mortality rate $<25 \%$ ) was first investigated by the WST-1 test. Cytotoxic assay was performed after a 24 -h treatment with NPs. The results show that exposure of HPAEC to FW2 NPs $\left(1-10 \mu \mathrm{g} / \mathrm{cm}^{2}\right)$ for $24 \mathrm{~h}$, decreased concentrationdependently cell viability (Fig. 2a). A statistically significant reduction in cell viability was observed for a concentration of $5 \mu \mathrm{g} / \mathrm{cm}^{2}(90.2 \%, P<0.05)$ and above. These results also show that mitochondrial activity of HPAEC decreased in a concentration-dependent manner upon FW2 NPs exposure. 

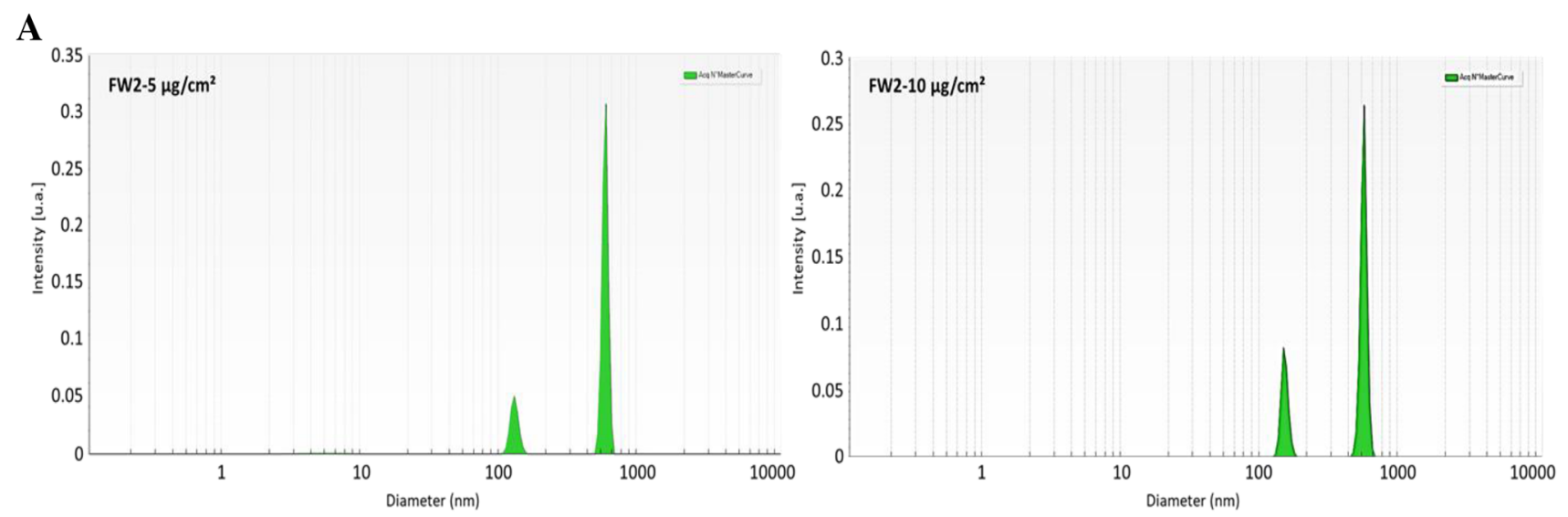

\begin{tabular}{|c|ccc|}
\cline { 2 - 4 } \multicolumn{1}{c|}{} & \multirow{2}{*}{} & Mean size (Intensity) & \multicolumn{2}{c|}{ Distribution (Intensity) } \\
\cline { 2 - 4 } \multicolumn{1}{c|}{} & & Peak 1 & Peak 2 \\
\hline FW2 $\mathbf{- 5} \boldsymbol{\mu g} / \mathbf{c m}^{\mathbf{2}}$ & $454 \mathrm{~nm}$ & $119 \pm 9 \mathrm{~nm}$ & $536 \pm 32 \mathrm{~nm}$ \\
\hline FW2 $\mathbf{1 0} \boldsymbol{\mathbf { g }} / \mathbf{c m}^{\mathbf{2}}$ & $417 \mathrm{~nm}$ & $139 \pm 10 \mathrm{~nm}$ & $515 \pm 34 \mathrm{~nm}$ \\
\hline
\end{tabular}

B

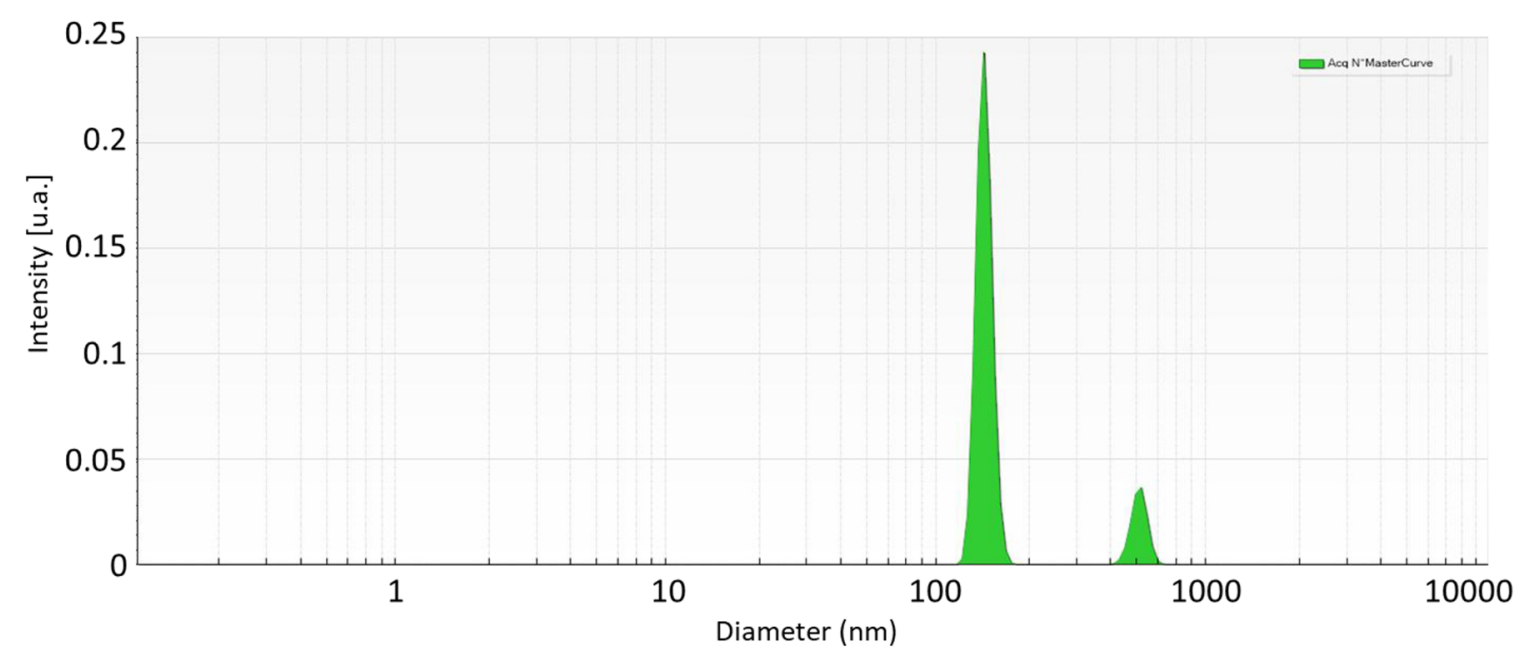

\begin{tabular}{|c|c|cc|}
\cline { 2 - 2 } \multicolumn{1}{c|}{} & Mean size (Number) & \multicolumn{2}{c|}{ Distribution (Number) } \\
\multicolumn{1}{c|}{} & Peak 1 & Peak 2 \\
\hline FW2 NPs & $187 \mathrm{~nm}$ & $136 \pm 10 \mathrm{~nm}$ & $510 \pm 38 \mathrm{~nm}$ \\
\hline
\end{tabular}

Fig. 1 Size distribution of FW2 NPs in endothelial cell growth medium measured by DLS. a Size distribution in intensity analyzed by SBL algorithm for two different concentrations of FW2 NPs sus-

\section{FW2 NPs increase intracellular ROS production}

Figure $2 \mathrm{~b}$ shows that a 4 -h exposure of HPAEC to FW2 NPs $\left(1-10 \mu \mathrm{g} / \mathrm{cm}^{2}\right)$ induced a significant concentrationdependent increase in intracellular global ROS production pended in ECGM and table of corresponding mean size values. b Size distribution in relative number of FW2 $\left(10 \mu \mathrm{g} / \mathrm{cm}^{2}\right)$ and corresponding mean size values

from $5 \mu \mathrm{g} / \mathrm{cm}^{2}(37.8 \%, P<0.001)$. The ability of FW2 NPS to specifically generate cytoplasmic superoxide anion $\left(\mathrm{O}_{2}{ }^{-}\right)$production in HPAEC (Fig. 2c) was then investigated by EPR. A 4-h exposure to FW2 NPs significantly 


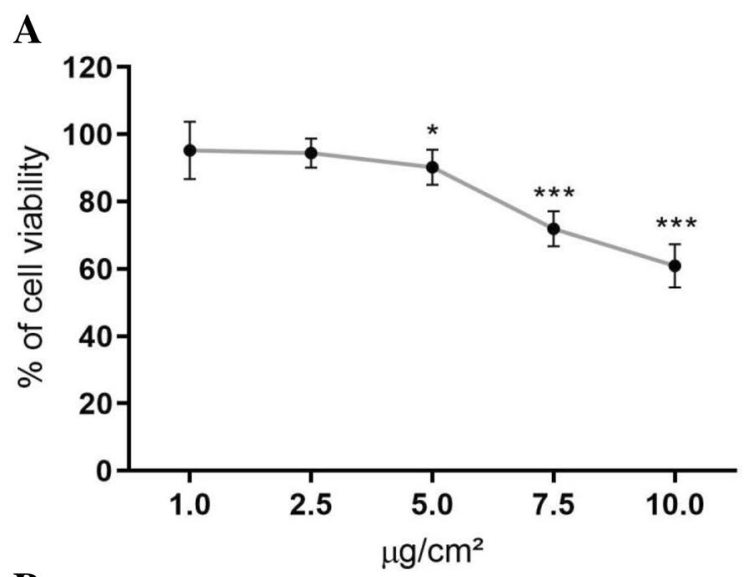

B
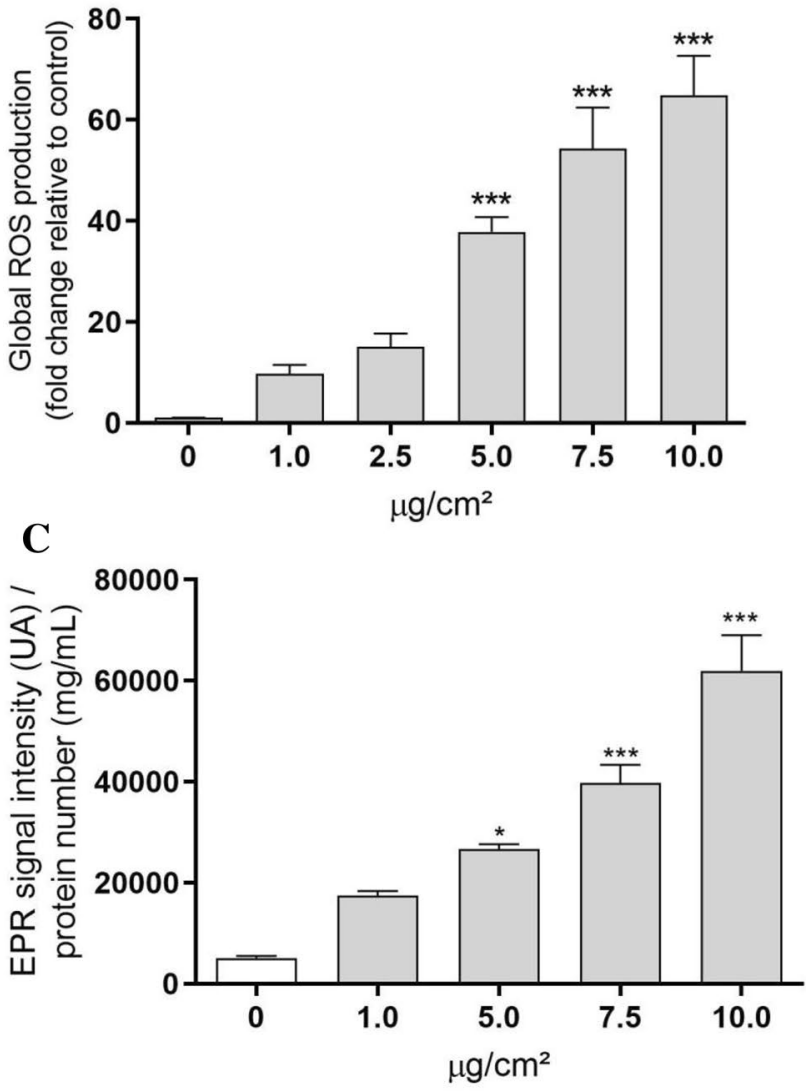

Fig. 2 Cell viability and intracellular ROS production in HPAEC. a Cell viability after 24-h exposure with FW2 NPs $\left(1-10 \mu \mathrm{g} / \mathrm{cm}^{2}\right)$ measured by WST-1 colorimetric assay. Results are expressed as the percentage of cell viability in treated cells, as compared to control cells (100\%). Data are mean \pm SEM of three independent experiments ( 8 wells/concentration). b ROS production after 4-h exposure with FW2 NPs was measured by spectrofluorimetry via $\mathrm{CM}-\mathrm{H}_{2}$ DCFDA probe assay. The values were normalized to untreated cells, and results are expressed as the fold change of $\mathrm{CM}-\mathrm{H}_{2} \mathrm{DCF}$ fluorescence intensity, relative to control cells. c Intracellular $\mathrm{O}_{2}^{-}$production after 4-h exposure with FW2 NPs, measured by EPR spectrometer with $\mathrm{CMH}$ probe. Results are expressed in EPR signal amplitude in arbitrary units (AU) $/ \mathrm{mg} / \mathrm{mL}$ of proteins. Data are mean \pm SEM of three independent experiments $(n=3)$, in triplicate. Statistically significant at $P<0.05(*), P<0.01(* *)$, and $P<0.001(* * *)$, as compared to control, according to Kruskal-Wallis test, followed by Dunn's Multiple Comparison test increased, in a concentration-dependent manner, cytoplasmic $\mathrm{O}_{2}^{-}$from $5 \mu \mathrm{g} / \mathrm{cm}^{2}(P<0.05)$.

\section{FW2 NPs increase cytosolic calcium concentration}

In a first set of experiments, it was investigated, by calcium imaging (Fluo-4, AM probe), whether a 4-h exposure to FW2 NPs increases cytoplasmic calcium concentration. Figure 3 a shows in HPAEC, a statistically significant and concentration-dependent increase $\left(5,7.5\right.$ and $\left.10 \mu \mathrm{g} / \mathrm{cm}^{2}\right)$ in the basal intracellular calcium ion level $\left[\mathrm{Ca}^{2+}\right]_{\mathrm{i}}(50.2 \%, 68.8 \%$ and $78.6 \%, P<0.001$ ). However, no effect on basal $\mathrm{Ca}^{2+}$ concentration was observed upon acute FW2 NPs exposure (5-10 min, data not shown). In a second set of experiments, to elucidate whether the FW2 NPs-induced impairment in intracellular calcium homeostasis was correlated to an increase in ROS production, the same experiments were performed using antioxidant enzymes. Pre-treatment $(1 \mathrm{~h})$ of HPAEC with both PEG-SOD and PEG-catalase, prior a 4-h exposure, had no significant effect on basal intracellular calcium level compared to control cells (21.4\%, "ns") (Fig. 3a). However, antioxidant enzymes fully reversed FW2 NPs-induced increase in intracellular calcium basal level in cells co-treated with FW2 NPs, thus indicating that ROS production was involved in $\mathrm{Ca}^{2+}$ signaling alterations. Several experiments were then performed to elucidate the mechanism of this effect. To assess the role of the extracellular source in $\left[\mathrm{Ca}^{2+}\right]_{\mathrm{i}}$ rise, HPAEC were exposed to FW2 NPs in the presence and in the absence of extracellular $\mathrm{Ca}^{2+}$. Before experiments, EGTA ( $5 \mathrm{mM}$ ) was added on ECGM for chelating $\mathrm{Ca}^{2+}$ ion. As shown in Fig. 3b, c, the absence of extracellular $\mathrm{Ca}^{2+}$ had no effect on FW2 NPs-induced $\mathrm{Ca}^{2+}$ response after 4-h exposure. This observation suggests that FW2 NPs-induced $\left[\mathrm{Ca}^{2+}\right]_{\mathrm{i}}$ rise could, thus, be mediated by intracellular $\mathrm{Ca}^{2+}$ stores. To confirm this hypothesis, the intracellular $\mathrm{Ca}^{2+}$ source and, more precisely, the release of $\mathrm{Ca}^{2+}$ from the ER, was investigated. The replenishment of the reticulum calcium store was first evaluated in the presence of adenosine triphosphate (ATP) $(20 \mu \mathrm{M})$ which induces, via $\mathrm{P} 2 \mathrm{Y}$ receptor, the inositol 1,4,5 triphosphate $\left(\mathrm{IP}_{3}\right)$ pathway activation leading to calcium release from the reticulum (Vishnu et al. 2014). Figure 4a shows that exposure of HPAEC to FW2 NPs significantly decreased, in a concentration-dependent manner, the ATP-induced calcium response from $5 \mu \mathrm{g} / \mathrm{cm}^{2}(-0.58$ Fmax/F0 Fluo-4, $P<0.001)$ as compared to control cells. After 1-h pre-treatment of HPAEC with both PEG-SOD and PEG-catalase, followed by 4-h FW2 NPs exposure, the antioxidant enzymes fully reversed the FW2 NPs-induced ATP response impairment. The involvement of $\mathrm{Ca}^{2+}$ from the ER was also investigated using thapsigargin $(1 \mu \mathrm{M})$, an ER $\mathrm{Ca}^{2+}$-ATPase (SERCA) inhibitor, to deplete the $\mathrm{Ca}^{2+}$ ER stores. After $4 \mathrm{~h}$ FW2 NPs exposure, thapsigargin-induced calcium release decreased, 
Fig. 3 Cytoplasmic basal calcium level $\left(\left[\mathrm{Ca}^{2+}\right]_{\mathrm{c}}\right)$ in HPAEC. Calcium level was measured with Fluo-4, AM probe $(1 \mu \mathrm{M})$, by confocal microscopy. a Effect of antioxidant enzymes: cells were exposed $4 \mathrm{~h}$ with FW2 NPs $\left(5-10 \mu \mathrm{g} / \mathrm{cm}^{2}\right)$ after or not 1-h pre-treatment with PEG-SOD $(600 \mathrm{U} / \mathrm{mL})$ and PEG-catalase $(300 \mathrm{U} / \mathrm{mL})$. b Effect of extracellular calcium on $\left[\mathrm{Ca}^{2+}\right]_{\mathrm{c}}$ level rise. HPAEC were exposed with FW2 NPs in the presence $\left(1.6-\mathrm{mM}\left[\mathrm{Ca}^{2+}\right] \mathrm{e}\right)$ or in absence of extracellular calcium $\left(0-\mathrm{mM}\left[\mathrm{Ca}^{2+}\right] \mathrm{e}\right)$. The values were normalized to untreated cells, and results are expressed as the fold change of Fluo-4 probe fluorescence intensity relative to control cells. c HPAEC imaging of Fluo-4, AM probe by confocal microscopy. Cells were exposed to FW2 NPs (4 h, $10 \mu \mathrm{g} / \mathrm{cm}^{2}$ ) in both conditions: $1.6-\mathrm{mM}\left[\mathrm{Ca}^{2+}\right] \mathrm{e}$ and $0-\mathrm{mM}\left[\mathrm{Ca}^{2+}\right]$ e. Data are Mean \pm SEM of three independent experiments $(n=3)$, (six wells/concentration). Statistically significant at

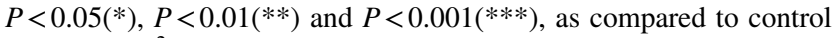
$1.6-\mathrm{mM}\left[\mathrm{Ca}^{2+}\right] \mathrm{e}$, statistically significant at $P<0.001$ (\#\#\#), as compared to cells pre-treated with antioxidants enzymes and statistically significant at $P<0.001(\$ \$ \$)$, as compared to control $0 \mathrm{mM}\left[\mathrm{Ca}^{2+}\right] \mathrm{e}$, according to ANOVA test, followed by Tukey's Multiple Comparison test. $n s$ no significant

in a concentration-dependent manner, from $5 \mu \mathrm{g} / \mathrm{cm}^{2}(-0.37$ $F \max / F 0$ Fluo-4, $P<0.001$ ) (Fig. 4b). Thus, ATP and thapsigargin experiments indicate that FW2 NPs exposure decreases calcium in ER. At last, to confirm whether the FW2 NPs-induced $\left[\mathrm{Ca}^{2+}\right]_{\mathrm{i}}$ rise was, indeed, mediated by ER $\left[\mathrm{Ca}^{2+}\right]$ stores, $\left[\mathrm{Ca}^{2+}\right]$ was measured in the ER by Fluo-4FF, AM probe with confocal microscopy (Fig. 4c). Results show that after 4-h FW2 NPs exposure, ER $\left[\mathrm{Ca}^{2+}\right]$ significantly decreased, in a concentration-dependant manner, from $5 \mu \mathrm{g} /$ $\mathrm{cm}^{2}(88.6 \%, P<0.001)$ as compared to control cells $(100 \%)$. These results suggest that FW2 NPs-induced $\left[\mathrm{Ca}^{2+}\right]_{i}$ rise mobilizes the ER source.

\section{FW2 NPs increase mitochondrial $\mathrm{O}_{2}^{-}$production}

The effect of FW2 NPs on mitochondrial $\mathrm{O}_{2}{ }^{-}$production was assessed by MitoSOX probe (confocal imaging). Figure 5 shows, after 4-h exposure of HPAEC to FW2 NPs, a statistically significant, concentration-dependent augmentation in mitochondrial $\mathrm{O}_{2}{ }^{-}$production $(5,7.5$ and $10 \mu \mathrm{g} /$ $\left.\mathrm{cm}^{2}\right)$ as compared to control cells $(67.1 \%, P<0.01 ; 150.2 \%$ and $223.8 \%, P<0.001)$. To elucidate whether FW2 NPsinduced mitochondrial oxidative stress was primarily related to cytosolic oxidative stress or to cytosolic calcium homeostasis alteration, the same experiments were performed using PEG-SOD (300 U/mL), PEG-CAT (600 U/mL) and BAPTA-AM $(5 \mu \mathrm{M})$, respectively. After a 1-h pre-treatment of HPAEC with both PEG-SOD and PEG-catalase, followed by a $4 \mathrm{~h}-\mathrm{FW} 2$ NPs exposure $\left(5,7.5\right.$ and $\left.10 \mu \mathrm{g} / \mathrm{cm}^{2}\right)$, FW2 NPs-induced mitochondrial $\mathrm{O}_{2}^{-}$production was significantly decreased as compared to FW2 NPs-treated cells (7.24\% and 42.6\%, "ns"; 68\%, P<0.01) (Fig. 5a, b). In cells co-treated with FW2 NPs and antioxidant enzymes, FW2 NPs-induced mitochondrial $\mathrm{O}_{2}{ }^{-}$production was fully reversed. In contrast, 30-min pre-treatment of HPAEC with BAPTA-AM,
A

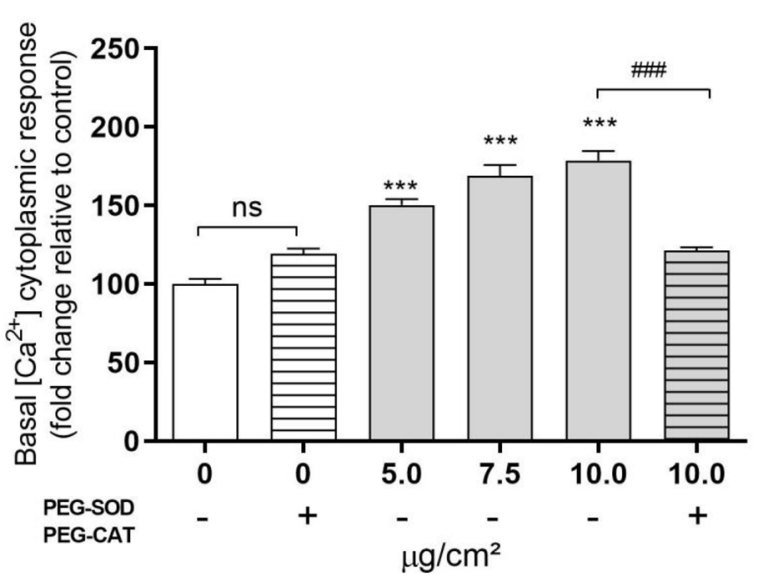

B

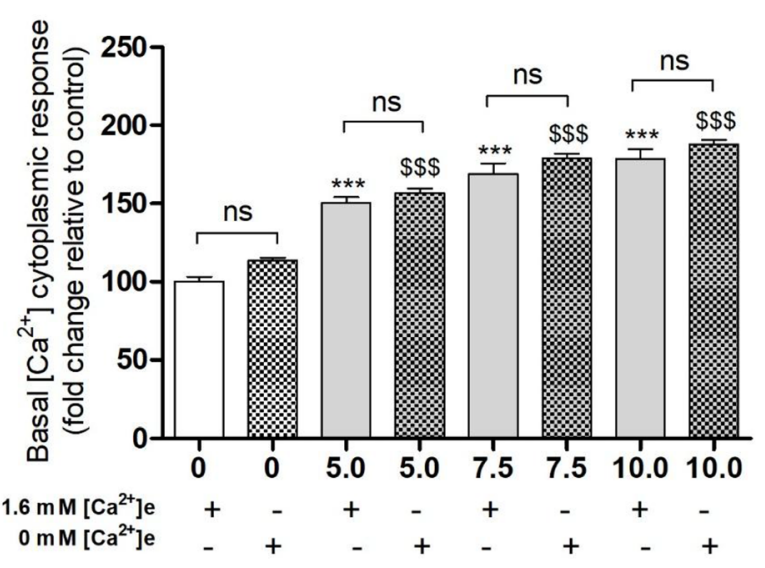

C

$\mu \mathrm{g} / \mathrm{cm}^{2}$

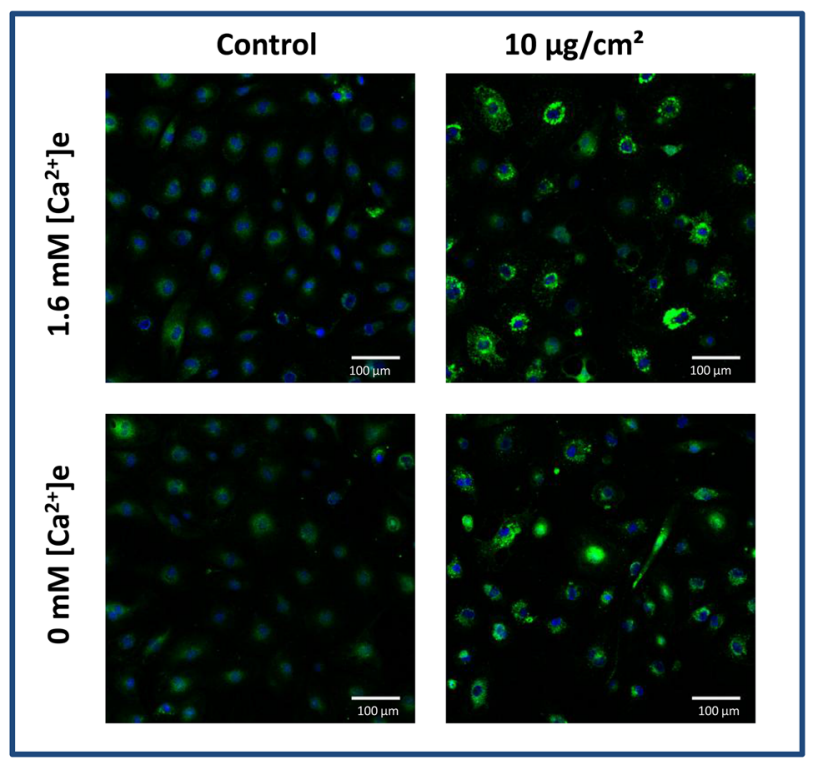

followed by 4-h FW2 NPs exposure, had no effect on FW2 NPs-induced mitochondrial $\mathrm{O}_{2}^{-}$production $(57 \%, P<0.01$; $144.2 \%$ and $231 \%, P<0.001$ ) (Fig. 5 c). These results indicate that change in cytosolic calcium is not involved in the mitochondrial $\mathrm{O}_{2}{ }^{-}$production. The global oxidative stress, thus, plays a key role on the mitochondrial $\mathrm{O}_{2}^{-}$production. 


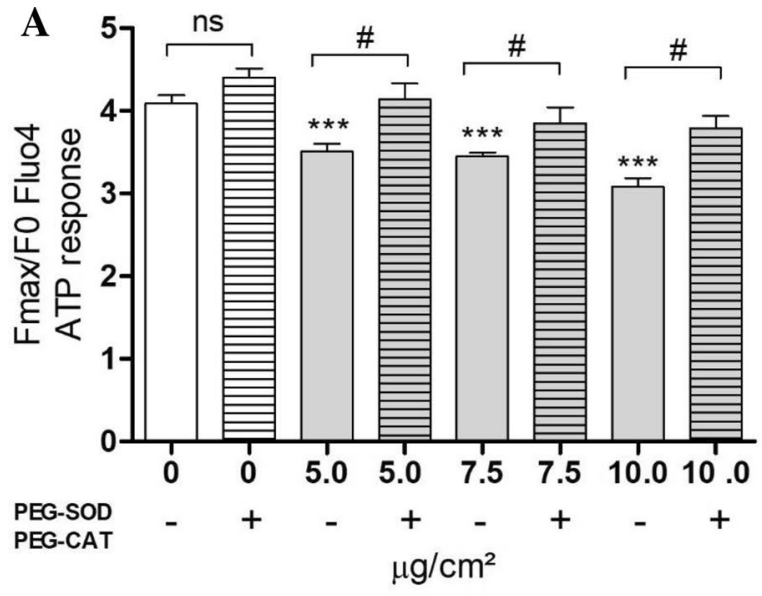

B
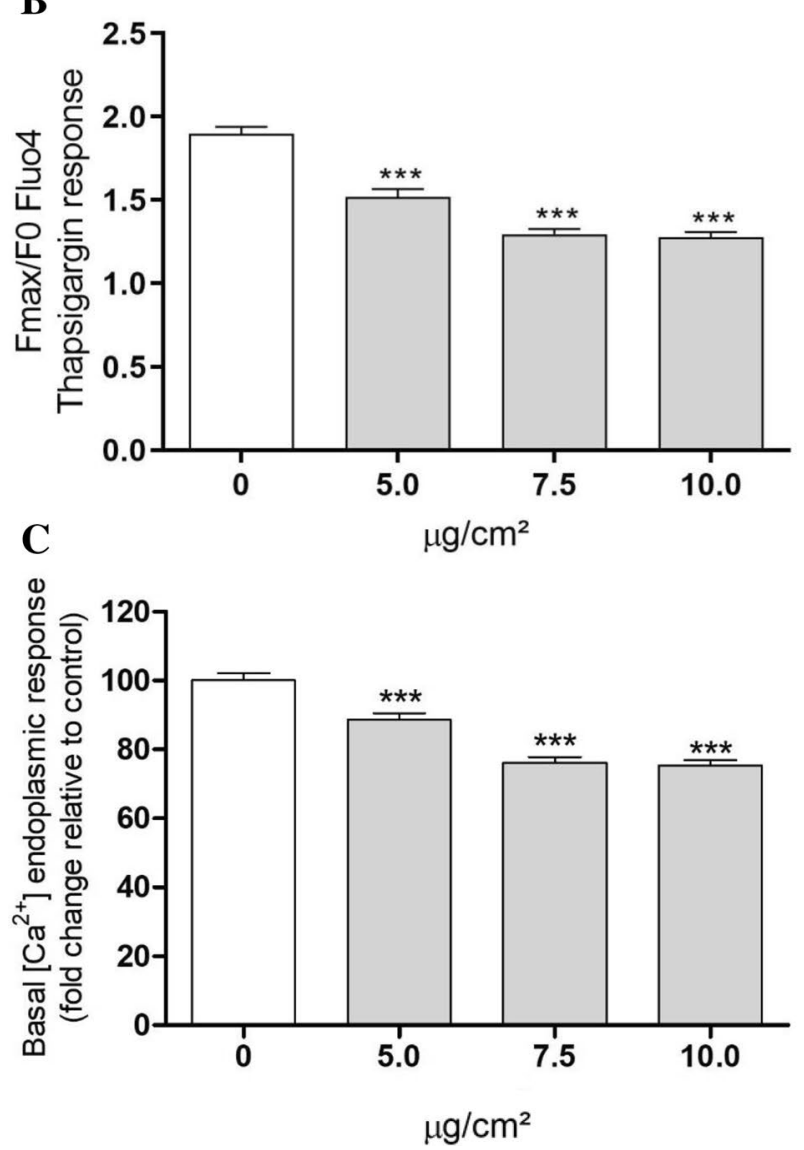

Fig. 4 Effect of endoplasmic reticulum on $\left[\mathrm{Ca}^{2+}\right] \mathrm{c}$ level rise. $\left[\mathrm{Ca}^{2+}\right] \mathrm{c}$ was measured with Fluo-4, AM probe $(1 \mu \mathrm{M})$ and $\left[\mathrm{Ca}^{2+}\right]_{\mathrm{ER}}$ with Fluo-4FF, AM probe $(10 \mu \mathrm{M})$, by confocal microscopy. a ATP response $(20 \mu \mathrm{M})$ in HPAEC exposed $4 \mathrm{~h}$ with FW2 NPs $\left(5-10 \mu \mathrm{g} / \mathrm{cm}^{2}\right)$ after or not 1 -h pre-treatment with PEG-SOD $(600 \mathrm{U} / \mathrm{mL})$ and PEG-catalase $(300 \mathrm{U} / \mathrm{mL})$. b Thapsigargin response $(1 \mu \mathrm{M})$ in HPAEC exposed with FW2 NPs. The values correspond to the fluorescence intensity of the response peak. $\mathbf{c}\left[\mathrm{Ca}^{2+}\right]$ variation in endoplasmic reticulum. The values were normalized to untreated cells, and results are expressed as the fold change of Fluo-4FF probe fluorescence intensity, relative to control cells. Data are mean \pm SEM of three independent experiments $(n=3)$, (six wells/concentration). Statistically significant at $P<0.05\left(^{*}\right)$, $P<0.01(* *)$ and $P<0.001$ (***), as compared to control, statistically significant at $P<0.05(\#)$, as compared to cells pre-treated with antioxidants enzymes, according to ANOVA test, followed by Tukey's Multiple Comparison test. $n s$ no significant

\section{FW2 NPs increase mitochondrial calcium level}

To determine the effect of FW2 NPs on mitochondrial calcium signaling in HPAEC, mitochondrial calcium concentration $\left(\left[\mathrm{Ca}^{2+}\right]_{\mathrm{m}}\right)$ was investigated after 4 -h exposure to FW2 NPs by calcium imaging (Rhod-2, AM probe). Figure 6a shows, in HPAEC, a statistically significant and concentration-dependent increase in $\left[\mathrm{Ca}^{2+}\right]_{\mathrm{m}}$ induced by FW2 NPs $\left(5,7.5\right.$ and $\left.10 \mu \mathrm{g} / \mathrm{cm}^{2}\right)$ as compared to control cells $(19.1 \%, P<0.01 ; 45.6 \%$ and $55.1 \%, P<0.001)$. To elucidate whether FW2 NPs-induced impairment in mitochondrial calcium homeostasis was primarily related to oxidative stress or to cytosolic calcium homeostasis alteration, the same experiments were performed using PEG-SOD (300 U/mL), PEG-CAT $(600 \mathrm{U} / \mathrm{mL})$ and BAPTA-AM $(5 \mu \mathrm{M})$, respectively. After 1-h pre-treatment of HPAEC with both PEG-SOD and PEG-catalase, followed by 4-h FW2 NPs exposure (5, 7.5 and $\left.10 \mu \mathrm{g} / \mathrm{cm}^{2}\right)$, no significant effect of FW2 NPs on $\left[\mathrm{Ca}^{2+}\right]_{\mathrm{m}}$ was observed as compared to control cells (8.6\%, 2.9\% and 1\%, "ns") (Fig. 6a). In contrast, 30-min pre-treatment of HPAEC with BAPTA-AM, followed by 4-h FW2 NPs exposure, had no effect on FW2 NPs-induced $\left[\mathrm{Ca}^{2+}\right]_{\mathrm{m}}$ rise $(6.7 \%$, $P<0.05 ; 33.4 \%$ and $55.2 \%, P<0.001$ ) (Fig. 6b, c). These results, thus, indicate that the increase in $\left[\mathrm{Ca}^{2+}\right]_{\mathrm{m}}$ seems to be related to cytosolic oxidative stress.

\section{FW2 NPs decrease mitochondrial membrane potential (YMP)}

The effect of FW2 NPs on YMP was assessed by TMRM probe (confocal imaging). The results show that 4-h exposure to FW2 NPs $\left(5,7.5\right.$ and $\left.10 \mu \mathrm{g} / \mathrm{cm}^{2}\right)$ in HPAEC significantly decreased $\Psi$ MP in a concentration-dependent manner $(59.7 \%, 50.1 \%$ and $43.7 \%, P<0.001)$ (Fig. 7). To elucidate whether FW2 NPs-induced YMP decline was primarily related to cytosolic oxidative stress or to cytosolic calcium homeostasis alteration, the same experiments were performed using PEG-SOD $(300 \mathrm{U} / \mathrm{mL})$, PEG-CAT $(600 \mathrm{U} / \mathrm{mL})$ and BAPTA-AM $(5 \mu \mathrm{M})$, respectively. After 1-h pre-treatment of HPAEC with both PEG-SOD and PEG-catalase, followed by 4-h FW2 NPs exposure $(5,7.5$ and $10 \mu \mathrm{g} / \mathrm{cm}^{2}$ ), FW2 NPs had no significant effect on YMP as compared to control cells $(98.3 \%, 105.1 \%$ and 92.9\%, "ns") (Fig. 7a, b). In contrast, 30-min pre-treatment of HPAEC with BAPTA-AM, followed by 4-h FW2 NPs exposure, had no effect on FW2 NPs-induced $\Psi$ MP decline $(53.1 \%, 49.2 \%$ and $42.3 \%, P<0.001)$ (Fig. 7 c). Likewise, these results indicate that the modification of YMP seems to be related to cytosolic oxidative stress. 
Fig. 5 Mitochondrial $\mathrm{O}_{2}^{-}\left(\mathrm{mt} \mathrm{O}_{2}^{-}\right)$production in HPAEC. $\mathrm{mt} \mathrm{O}_{2}^{-}$ was measured with MitoSOX probe $(5 \mu \mathrm{M})$, by confocal microscopy. a Effect of antioxidants enzymes: cells were exposed $4 \mathrm{~h}$ with FW2 NPs $\left(5-10 \mu \mathrm{g} / \mathrm{cm}^{2}\right)$ after or not 1 -h pre-treatment with PEG-SOD $(600 \mathrm{U} / \mathrm{mL})$ and PEG-catalase $(300 \mathrm{U} / \mathrm{mL})$. b HPAEC imaging of MitoSOX probe by confocal microscopy. Cells were exposed with FW2 NPs $\left(10 \mu \mathrm{g} / \mathrm{cm}^{2}\right)$ in both conditions (with and without antioxidant enzymes). c Effect of extracellular calcium on $\mathrm{mt}_{2}{ }^{-}$level rise: cells were exposed with FW2 NPs after 30-min pre-treatment with an intracellular calcium chelator (BAPTA-AM, $5 \mu \mathrm{M}$ ). The values were normalized to untreated cells, and results are expressed as the fold change of MitoSOX probe fluorescence intensity, relative to control cells. Data are mean \pm SEM of three independent experiments $(n=3)$, (six wells/concentration). Statistically significant at $P<0.01(* *)$ and $P<0.001$ (***), as compared to controls, statistically significant at $P<0.05$ (\#) and $P<0.001$ (\#\#\#), as compared to cells pre-treated with antioxidants enzymes, statistically significant at $P<0.01(\$ \$)$ and $P<0.001$ (\$\$), as compared to control with BAPTA-AM, according to ANOVA test, followed by Tukey's Multiple Comparison test. $n s$ no significant

\section{FW2 NPs internalization in HPAEC and mitochondria ultra-structure observation}

Transmission electronic microscopy (TEM) was performed to obtain information on the uptake and localization of FW2 NPs in HPAEC after 1-h exposure to FW2 NPs $\left(7.5 \mu \mathrm{g} / \mathrm{cm}^{2}\right)$. Representative micrographs are shown in Fig. 8. After a rapid internalization into cells, FW2 NPs were mainly clustered into vesicles (Fig. 8a2, b2, b3). Internalized NPs were mostly organized in aggregates of various sizes; , whereas single or isolated NPs were rarely observed. TEM images evidence that FW2 NPs were also localized very close to mitochondria (Fig. 8b2, b3) or to the nucleus (Fig. 8b2). However, no particles were observed inside these elements. In addition, Fig. 8b2, b3) reveals changes in mitochondria morphology such as mitochondria swelling, decrease or even disappearance of mitochondrial cristae and vacuolization in FW2 NPs-treated cells as compared to control cells with normal intact mitochondria.

\section{FW2 NPs impair mitochondrial dynamic}

The effect of FW2 NPs $\left(7.5 \mu \mathrm{g} / \mathrm{cm}^{2}\right)$ on mitochondrial dynamic was then examined using a specific mitochondrial Mitotracker probe (confocal imaging), after 4-h exposure to HPAEC. In negative controls, the mitochondrial network was dynamic showing typical fiber-like structure (Fig. 9a). In positive control treated with CCCP $(5 \mu \mathrm{M})$, a compound that induces fission of the network (Itoh et al. 2006), mitochondria presented fragmentation and appeared as disconnected fragments (Fig. 9c). FW2 NPs-treated cells (7.5 $\mu \mathrm{g} /$ $\mathrm{cm}^{2}$ ) revealed mitochondria fragmentation (Fig. 9b), similar to that of cells treated with CCCP, suggesting a mitochondria network alteration.
A
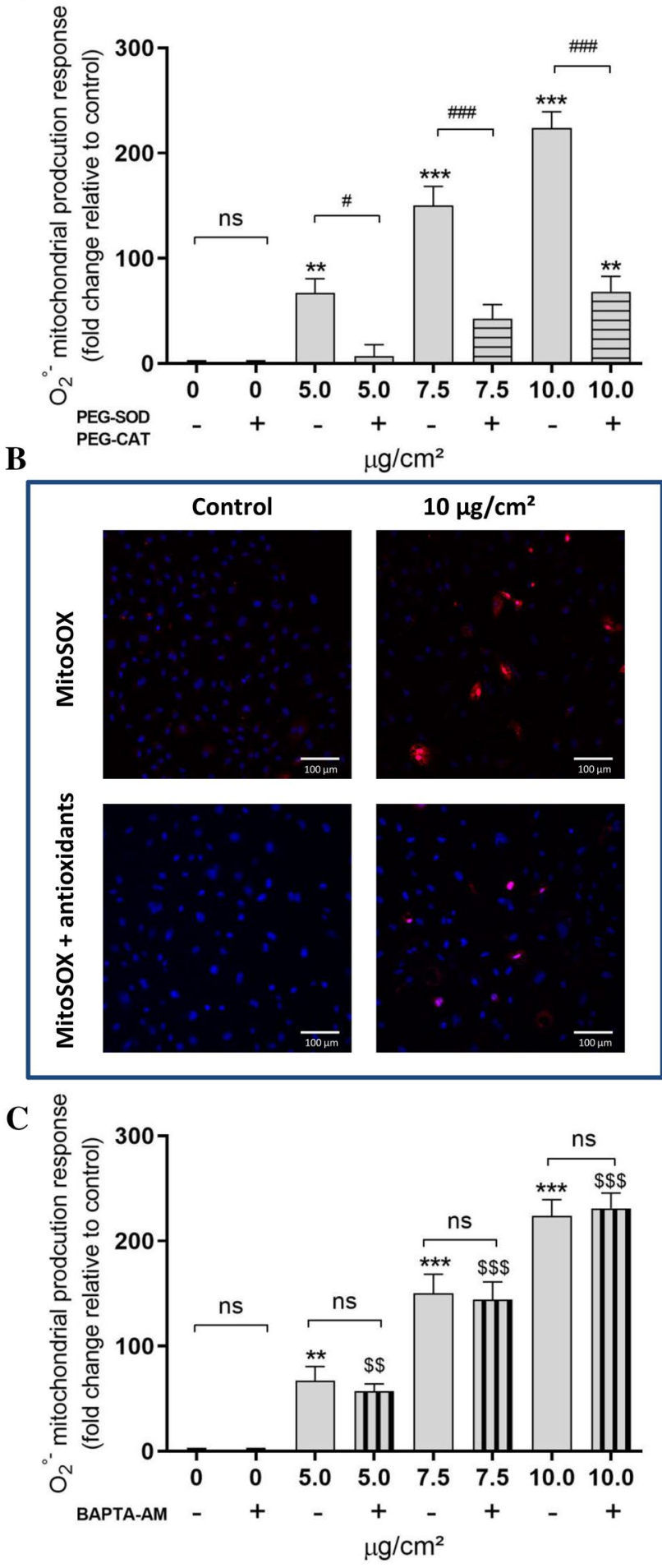

FW2 NPs induce apoptosis

The effect of FW2 NPs was finally assessed on cell death (apoptosis) using a specific caspase- 9 probe (confocal imaging) after 24-h exposure to HPAEC. In positive controls, $\mathrm{H}_{2} \mathrm{O}_{2}(250 \mu \mathrm{M})$ exposure induced apoptosis. In FW2 
Fig. 6 Mitochondrial calcium level $\left(\left[\mathrm{Ca}^{2+}\right]_{\mathrm{m}}\right)$ in HPAEC. $\left[\mathrm{Ca}^{2+}\right]_{\mathrm{m}}$ • was measured with Rhod-2-AM probe $(1 \mu \mathrm{M})$, by confocal microscopy. a Effect of antioxidants enzymes: cells were exposed $4 \mathrm{~h}$ with FW2 NPs $\left(5-10 \mu \mathrm{g} / \mathrm{cm}^{2}\right)$ after or not 1-h pre-treatment with PEGSOD $(600 \mathrm{U} / \mathrm{mL})$ and PEG-catalase $(300 \mathrm{U} / \mathrm{mL})$. b Effect of cytoplasmic calcium on $\left[\mathrm{Ca}^{2+}\right]_{\mathrm{m}}$ : cells were exposed with FW2 NPs after 30-min pre-treatment with an intracellular calcium chelator (BAPTA-AM $5 \mu \mathrm{M}$ ). The values were normalized to untreated cells, and results are expressed as the fold change of Rhod-2 probe fluorescence intensity, relative to control cells. c HPAEC imaging of Rhod2, AM probe by confocal microscopy. Cells were exposed with FW2 NPs $\left(7.5 \mu \mathrm{g} / \mathrm{cm}^{2}\right)$ in both conditions (with and without BAPTA-AM). Data are mean \pm SEM of three independent experiments $(n=3)$, (six wells/concentration). Statistically significant at $P<0.01(* *)$ and $P<0.001(* * *)$, as compared to controls, statistically significant at $P<0.001$ (\#\#\#), as compared to cells pre-treated with antioxidants enzymes, statistically significant at $P<0.05(\$)$ and $P<0.001(\$ \$ \$)$, as compared to control with BAPTA-AM, according to ANOVA test, followed by Tukey's Multiple Comparison test. "ns" meaning no significant

NPs-treated cells $\left(5,7.5\right.$ and $\left.10 \mu \mathrm{g} / \mathrm{cm}^{2}\right)$ caspase-9 fluorescence significantly increased, in a concentration-dependent manner $(39.7 \%, 70.8 \%$ and $94.9 \%, P<0.001)$ (Fig. 10), suggesting the induction of intrinsic apoptosis.

\section{Discussion}

The present study was designed to assess the effect of FW2 NPs in HPAEC target cells, to better understand the underliyng toxic mechanisms with special attention to calcium signaling, a key factor in vascular diseases (Berridge et al. 2003). First, we demonstrated that FW2 NPs induce a global overproduction of ROS and increase some free radicals, in particular $\mathrm{O}_{2}^{-}$(Fig. 2b, c). These data are in line with those reported for silica nanoparticles (Guo et al. 2015). In HPAEC, FW2 NPs also increased, concentration-dependently, basal $\left[\mathrm{Ca}^{2+}\right]_{\mathrm{i}}$ (Fig. 3a). This effect was strongly reduced by pre-treatment with antioxidant enzymes, thus suggesting that FW2 NPs-induced alteration in intracellular calcium homeostasis was also closely related to an increase in $\mathrm{O}_{2}{ }^{-}$and $\mathrm{H}_{2} \mathrm{O}_{2}$. Previous results have shown that calcium response in HPAEC differs according to particles type. FW2 NPs response is higher than that to $\mathrm{PM}_{2.5}$ particles (Deweirdt et al. 2017), this difference being likely related to physicochemical characteristics of particles (composition, size, solubility, etc.) which determine their biological effects. In previous studies, it was demonstrated, in other vascular cells type such as PASM, that $\mathrm{SiO}_{2} \mathrm{NPs}$-induced $\left[\mathrm{Ca}^{2+}\right]_{\mathrm{i}}$ rise involved the two main sources of calcium: the extracellular source, through the activation of both L-type $\mathrm{Ca}^{2+}$ and transient receptor potential vanilloid (TRPV) channels, and the intracellular source via the activation of ER receptors (Dubes et al. 2017). In contrast, the present findings
A

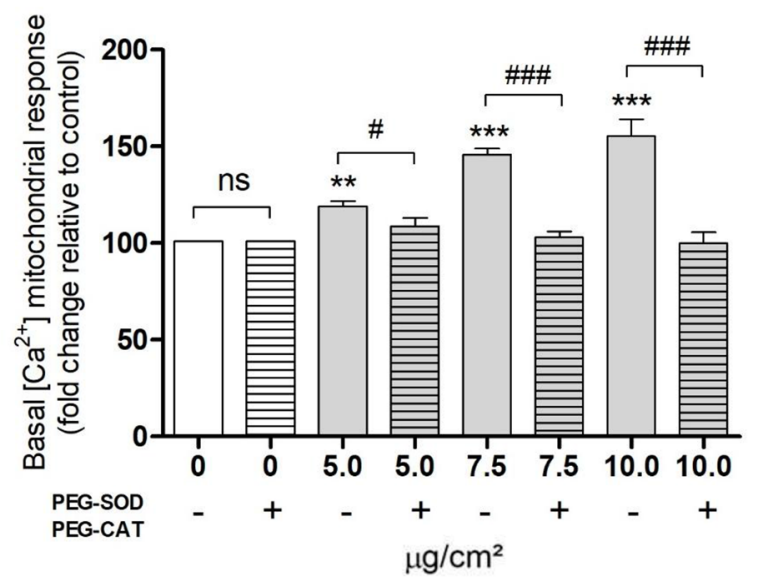

B
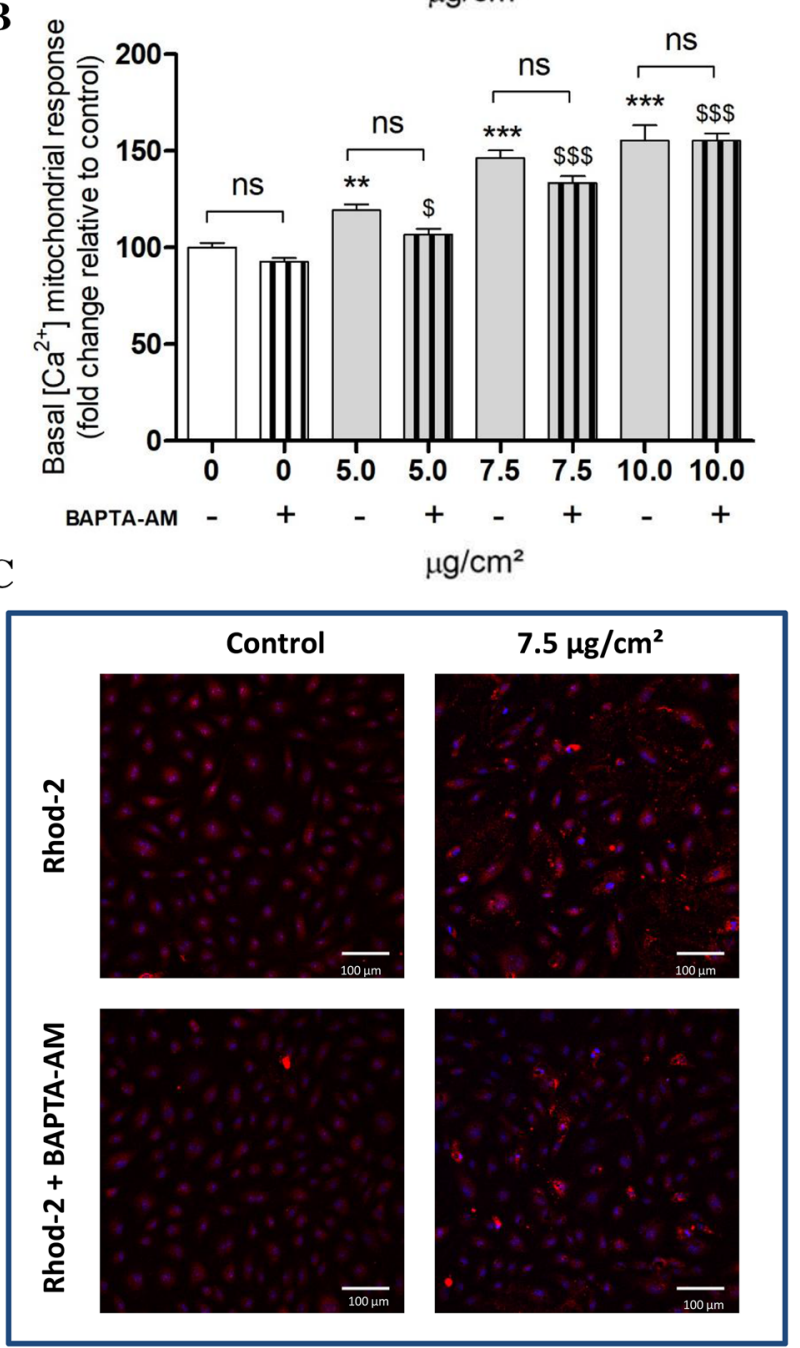

suggest that FW2 NPs-induced $\left[\mathrm{Ca}^{2+}\right]_{\mathrm{i}}$ rise does not involve the extracellular source of calcium, since the absence of extracellular calcium had no effect (Fig. 3b). One of the reasons for this discrepancy could be the lack of expression of L-type $\mathrm{Ca}^{2+}$ channels in HPAEC (Oshima et al. 2005) even though TRPV channels are present (Cioffi 2011; Goedicke-Fritz et al. 2015). An alternative 
Fig. 7 Mitochondrial Membrane Potential (YMP) in HPAEC. YMP was measured with TMRM probe $(100 \mathrm{nM})$, by confocal microscopy. a Effect of antioxidants enzymes: cells were exposed 4 h with FW2 NPs $\left(5-10 \mu \mathrm{g} / \mathrm{cm}^{2}\right)$ after or not 1-h pre-treatment with PEG-SOD $(600 \mathrm{U} / \mathrm{mL})$ and PEG-catalase $(300 \mathrm{U} / \mathrm{mL})$. b HPAEC imaging of TMRM probe by confocal microscopy. Cells were exposed with FW2 NPs $\left(10 \mu \mathrm{g} / \mathrm{cm}^{2}\right)$ in both conditions (with and without PEG-SOD and PEG-catalase). c Effect of $\left[\mathrm{Ca}^{2+}\right] \mathrm{c}$ on the YMP: cells were exposed with FW2 NPs after 30-min pre-treatment with an intracellular calcium chelator (BAPTA-AM, $5 \mu \mathrm{M}$ ). YMP level was expressed as the fluorescence intensity of TMRM probe, and was compared to untreated cells. Data are mean \pm SEM of three independent experiments $(n=3)$, (six wells/concentration). Statistically significant at $P<0.01(* *)$ and $P<0.001(* * *)$, as compared to controls, statistically significant at $P<0.001$ (\#\#\#), as compared to cells pre-treated with antioxidant enzymes, statistically significant at $P<0.001(\$ \$ \$)$ as compared to control with BAPTA-AM, according to ANOVA test, followed by Tukey's Multiple Comparison test. $n s$ no significant

signaling pathway implicating the intracellular $\mathrm{Ca}^{2+}$ stores (such as ER) is therefore probably active. ER is an important organelle involved in different cellular functions including protein synthesis and acts as the main intracellular calcium store in endothelial cells (Bagur and Hajnoczky 2017). We found that exposure of HPAEC to FW2 NPs significantly decreased, in a concentrationdependent manner: (i) the ATP-induced calcium response; (ii) the thapsigargin response; and finally (iii) the ER $\left[\mathrm{Ca}^{2+}\right]$ content (Fig. 4). Data also show a decrease in ER $\left[\mathrm{Ca}^{2+}\right]$ and an increase in basal $\left[\mathrm{Ca}^{2+}\right]_{\mathrm{c}}$ after FW2 NPs exposure corresponding to a calcium outflow from the ER into the cytosol. The impairment of ATP-induced calcium response was strongly reduced by a pre-treatment with antioxidant enzymes (Fig. 4a) confirming that FW2 NPsinduced alteration of intracellular signaling is indeed closely correlated with oxidative stress. Collectively, these data suggest that FW2 NPs-induced $\left[\mathrm{Ca}^{2+}\right]_{\mathrm{i}}$ increase is mediated via release of the intracellular calcium source by disruption of ER calcium stores. Previous studies have shown the role of $\mathrm{H}_{2} \mathrm{O}_{2}$ in ER stress via oxidation of proteins in cysteine, tyrosine and tryptophan residues (Sharov and Schoneich 2000). Oxidative stress can also break the S-S bonds or/and create new ones within proteins or peptides, which leads to ER disruption (van der Wijk et al. 2004). The following two mechanisms may be involved: (i) constant leakage of $\mathrm{Ca}^{2+}$ from the ER to the cytosol due to the protein oxidation via ROS overproduction (Bhandary et al. 2012), and/or (ii) SERCA pump disruption (Evangelista et al. 2012). ER stress is tightly related to oxidative stress and to mitochondrial damages (Deniaud et al. 2008). However, the mechanism by which FW2 NPs interact with this intracellular target and induces HPAEC mitochondria dysfunction has not yet been investigated. We show, here, that after rapid (1-h) internalization into cells, FW2 NPs were mainly clustered into vesicles, organized in aggregates and rarely free in
A

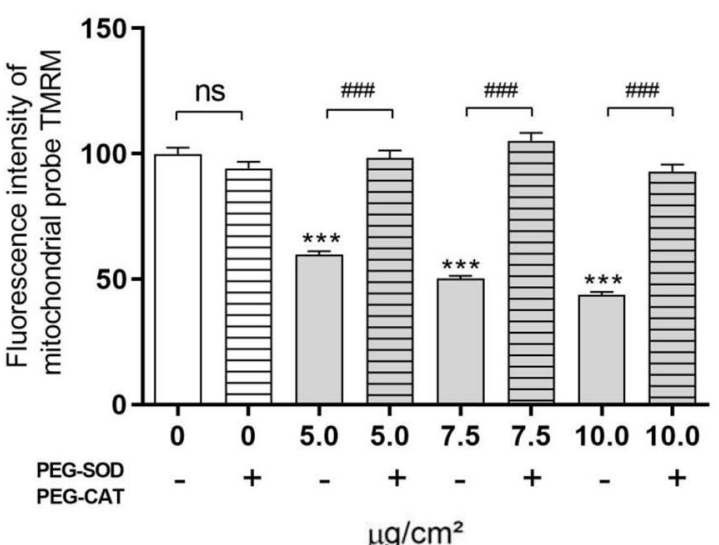

B

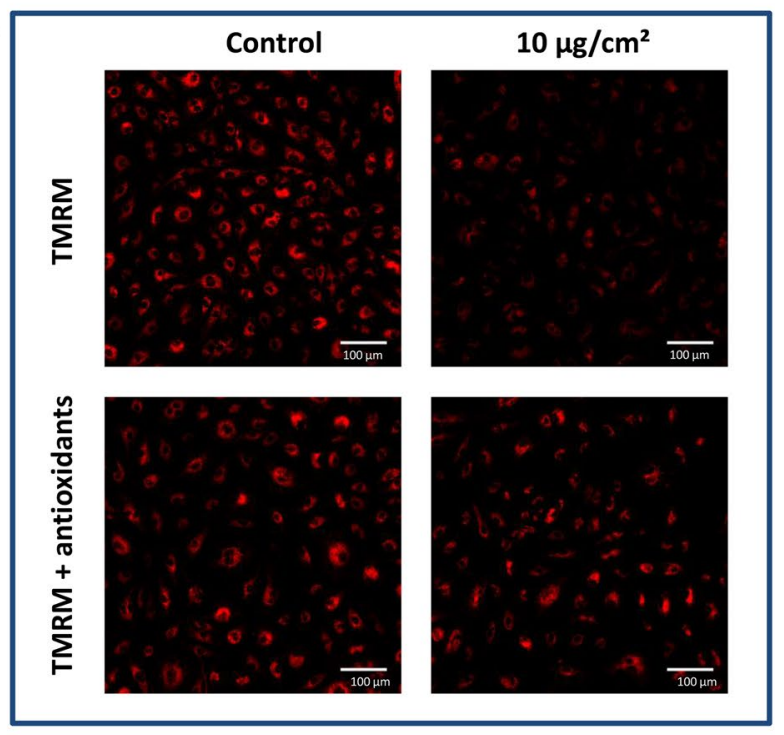

C

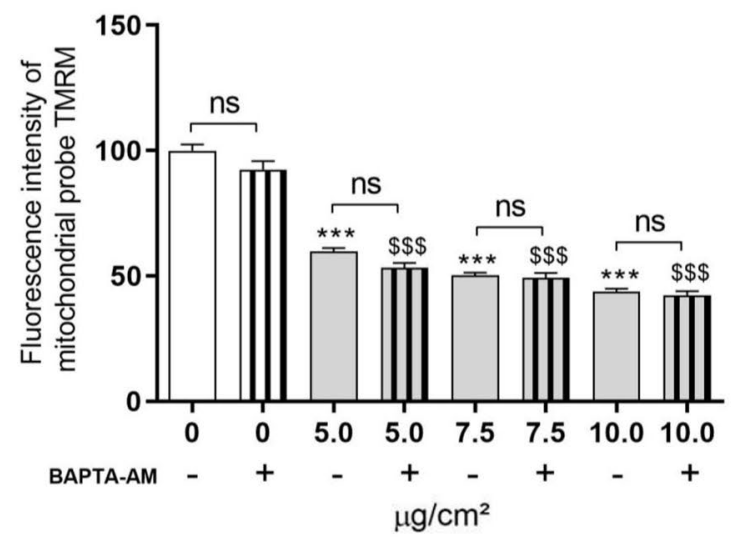

the cytoplasm (Fig. 8). Whereas no particles were actually found into mitochondria, the presence of FW2 NPs very close to mitochondria and the overproduction of intracellular ROS suggest that the function of this organelle could be impaired. The present data reveal an increase in mitochondria endogenous $\mathrm{O}_{2}{ }^{-}$production (from $5 \mu \mathrm{g} / \mathrm{cm}^{2}$, Fig. 5). Interestingly, at the same concentration, FW2 NPs decrease slightly $(<25 \%)$, but significantly, 
A

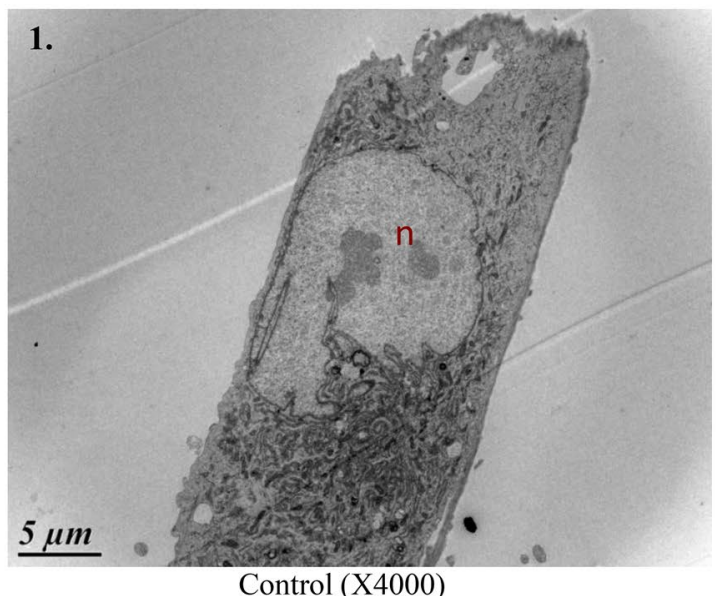

B
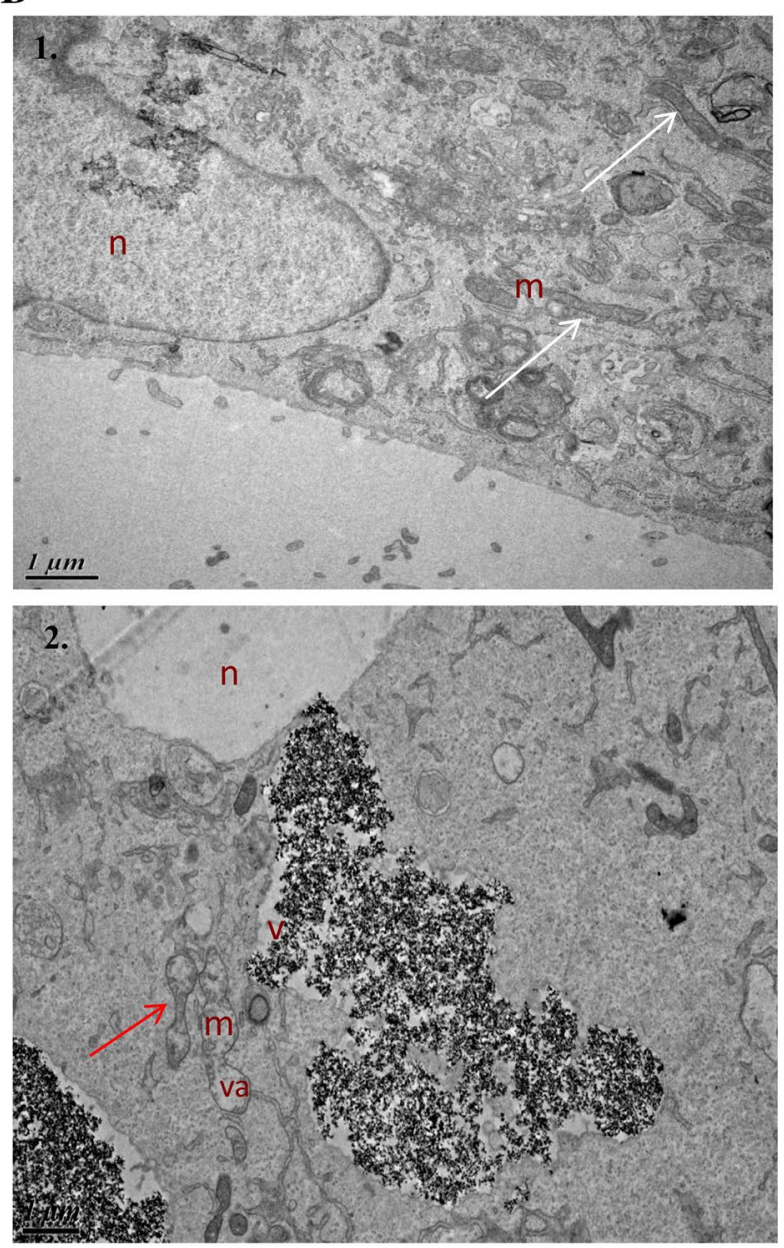

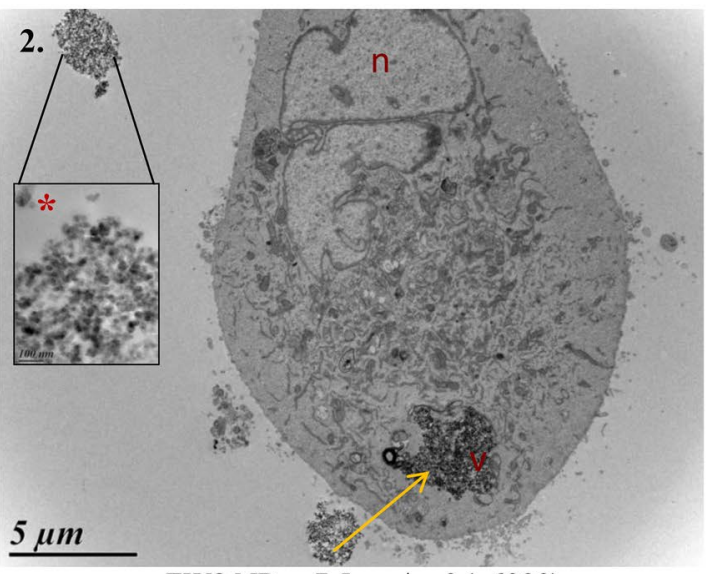

FW2 NPs - $7.5 \mu \mathrm{g} / \mathrm{cm}^{2}(\mathrm{x} 6000)$

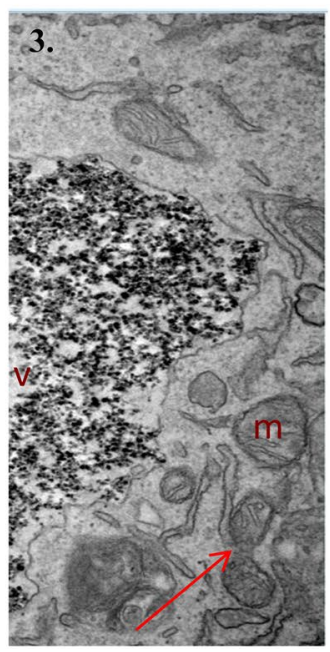

Fig. 8 HPAEC observed by transmission electronic microscope (TEM). a HPAEC observed by TEM. a1: Untreated cells, control $(\times 4000)$. a2: FW2 NPs $\left(7.5 \mu \mathrm{g} / \mathrm{cm}^{2}\right)$ internalization and intracellular localization in HPAEC, after 1 -h exposure $(\times 6000)$. b HPAEC morphological changes in mitochondria. b1: Untreated cells, control $(\times 11,000)$. b2 and b3: HPAEC after 1-h exposure with FW2 NPs $(\times 12,000$ and $\times 30,000)$. *Representative TEM image of FW2 NPs in ECGM $(\times 200,000)$. Orange arrow shows intracellular FW2 NPs aggregate. White arrows show intact mitochondria. Red arrows show mitochondria alterations. $n$ nucleus, $m$ mitochondria, $v$ vesicles, $v a$ vacuole (color figure online) 
Fig. 9 FW2 NPs-induced mitochondrial dynamic alterations. The mitochondrial dynamic was measured with Mitotracker probe $(1 \mu \mathrm{M})$, by confocal microscopy. a HPAEC untreated, negative control (×600). b FW2 NPs (7.5 $\mu \mathrm{g} /$ $\mathrm{cm}^{2}$ ) treated cells for $4 \mathrm{~h}$ ( $\times 600)$. c HPAEC exposed with CCCP $(5 \mu \mathrm{M})$, positive control $(\times 600)$. White arrows show typical fiber-like morphology. Red arrows show mitochondria fragmentation

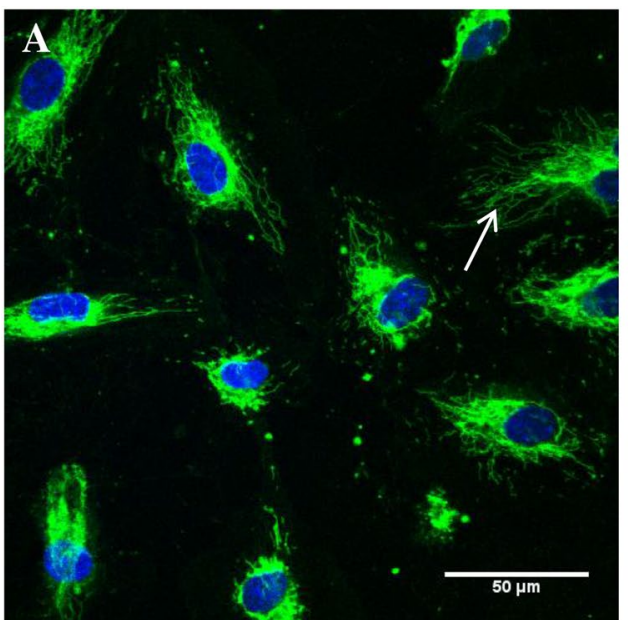

Control

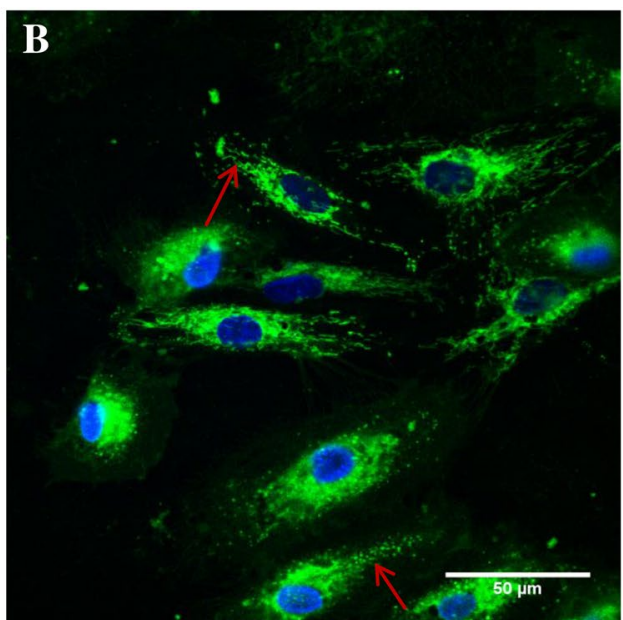

FW2 NPs - $7.5 \mu \mathrm{g} / \mathrm{cm}^{2}$

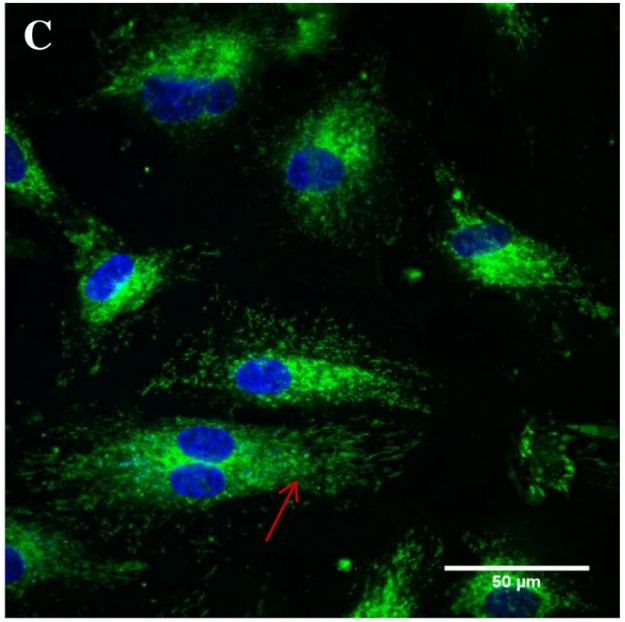

$\operatorname{CCCP}(5 \mu \mathrm{M})$

mitochondrial activity (measured by WST-1 assay) in HPAEC, which could be correlated with overproduction of mitochondrial $\mathrm{O}_{2}{ }^{-}$(Fig. 2a), although the present results do not exclude the involvement of NOX-induced $\mathrm{O}_{2}{ }^{-}$production. This decrease in mitochondrial activity could be correlated with a reduction in HPAEC cell viability. FW2 NPs exposure-induced increase in mitochondrial oxidative stress could alter mitochondria, exacerbating intracellular ROS production, thus generating a vicious cycle that contributes to the physiopathology of vascular diseases (Zhang and Gutterman 2007). Mitochondria also act as a calcium buffer site that cooperates with ER to regulate the intracellular calcium homeostasis (Marchi et al. 2018). By increasing mitochondrial ROS, FW2 NPs-induced mitochondrial alteration could, in turn, account for calcium homeostasis alteration induced by these particles. Indeed, $\left[\mathrm{Ca}^{2+}\right]_{\mathrm{m}}$ increase was strongly reduced by a pre-treatment with antioxidant enzymes, confirming that FW2 NPs-induced alteration in mitochondrial calcium homeostasis was closely correlated with an increase in $\mathrm{O}_{2}{ }^{-}$(Fig. 6a). Results with the intracellular calcium chelator (BAPTA-AM) suggest that the increase in $\left[\mathrm{Ca}^{2+}\right]_{\mathrm{m}}$ is not associated with a cytosolic effect (Fig. 6b). However, it can be hypothesized that calcium may directly pass from the reticulum to mitochondria via the Mitochondria-Associated ER Membrane (MAM) (Ma et al. 2017; Yu et al. 2015). Alternatively, it can be also speculated that the up-regulated $\left[\mathrm{Ca}^{2+}\right]_{\mathrm{m}}$ could be explained by the inhibition of $\mathrm{Na}^{+} / \mathrm{Ca}^{2+}$ mitochondrial activity exchanger (Guo et al. 2013) which limits the release of calcium from the mitochondria leading, in turn, to an increase in $\left[\mathrm{Ca}^{2+}\right]_{\mathrm{m}}$. FW2 NPs-induced mitochondrial membrane depolarization could also be explained by mitochondrial ROS over-production since $\Psi$ MP decrease was significantly attenuated by inhibition of oxidative pathways (Fig. 7). It can be assumed that increased $\left[\mathrm{Ca}^{2+}\right]_{\mathrm{m}}$, along with mitochondrial $\mathrm{O}_{2}^{-}$overproduction in mitochondrial matrix, could open the mPT and release 

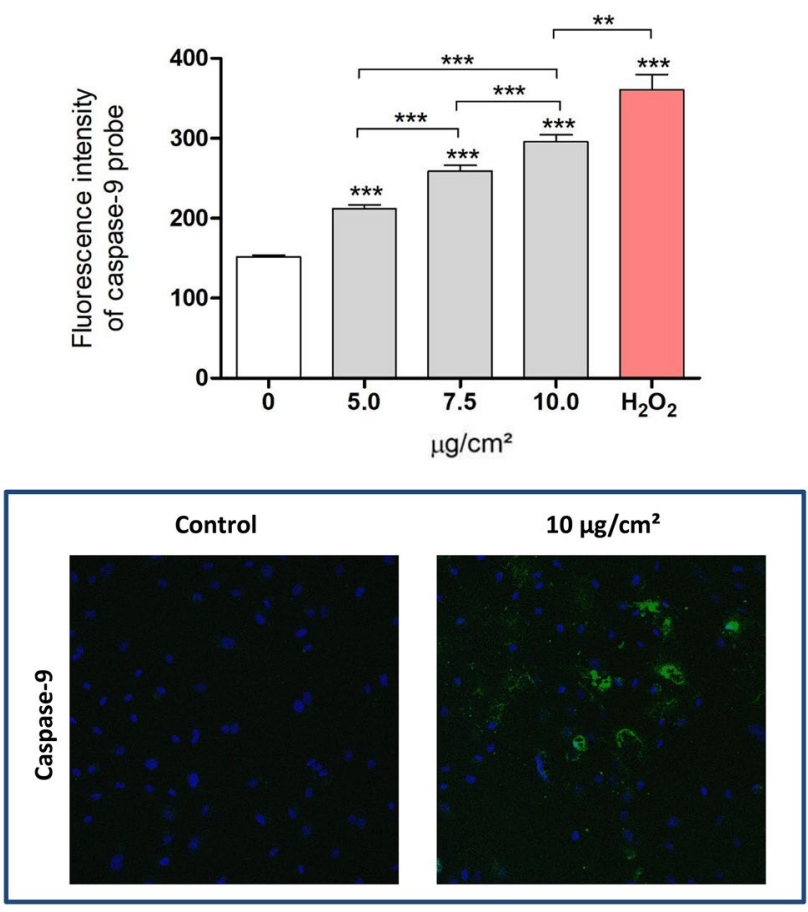

Fig. 10 FW2 NPs-induced apoptosis in HPAEC. Caspase-9 activity was measured with FAM-FLICA ${ }^{\circledR}$ Caspase 9 probe, by confocal microscopy. Cells were exposed with FW2 NPs $\left(5-10 \mu \mathrm{g} / \mathrm{cm}^{2}\right)$ during $24 \mathrm{~h}$. Caspase-9 fluorescence level was expressed as the fluorescence intensity of caspase- 9 probe, and was compared to untreated cells. Data are mean \pm SEM of three independent experiments $(n=3)$, (six wells/concentration). Statistically significant at $P<0.01(* *)$ and $P<0.001(* * *)$, as compared to controls, according to ANOVA test, followed by Tukey's Multiple Comparison test

cytochrome $c$ (often associated with lowering of transmembrane potential $\Delta \Psi \mathrm{m}$ ), which then induces apoptotic cell death (Choi et al. 2017). Indeed, our final results show a concentration-dependent increase in caspase 9 activity after exposure to FW2 NPs, suggesting an intrinsic apoptosis (Fig. 10). In this connection, it has been shown that alteration in mitochondrial morphology induces mitochondrial membrane depolarization (Westermann 2010). Moreover, cellular uptake and trafficking of NPs play a key role in NPs-induced toxicity. Despite the fact that FW2 NPs were not observed in mitochondria and nucleus after internalization, large aggregates of FW2 NPs were present very close to mitochondria, and could critically interfere with mitochondrial functions. Some studies have reported that $\mathrm{NPs}\left(\mathrm{SiO}_{2}, \mathrm{Fe}_{2} \mathrm{O}_{3}\right)$ cause mitochondrial swelling, cristae disruption or disappearance and mitochondria vacuolization in several cell types (Faisal et al. 2016). Regarding mitochondria biogenesis and dynamic, this study provides evidence that FW2 NPs induce morphological and structural alterations (Fig. 8). The fact that mitochondrial dynamics alterations (fusion/ fission equilibrium perturbation) do alter mitochondrial morphology (Zamponi et al. 2018) supports the present findings (Fig. 9). Overall results are summarized in Fig. 11.

\section{Conclusion}

The present study shows that, once internalized, FW2 NPs primarily activate intracellular ROS generation, leading to $\left[\mathrm{Ca}^{2+}\right]_{\mathrm{i}}$ rise. Global ROS production then induces: (i) overproduction of mitochondrial $\mathrm{O}_{2}^{-}$, leading to $\left[\mathrm{Ca}^{2+}\right]_{\mathrm{m}}$ rise; (ii) YMP depolarization, resulting in mitochondrial dynamics alterations responsible for mitochondrial morphology modification; (iii) ER disturbance; and (iv) induction of apoptosis as a consequence of all these toxic effects. In summary, ROS overproduction, along with high surface reactivity of FW2 NPs, targets both mitochondria and ER, two calcium buffer sites that cooperate to regulate intracellular calcium homeostasis. This study, thus, reveals that intracellular calcium homeostasis is the main intracellular target of FW2 NPs that could lead to endothelial dysfunction, a critical event involved in cardiovascular diseases physiopathology. 


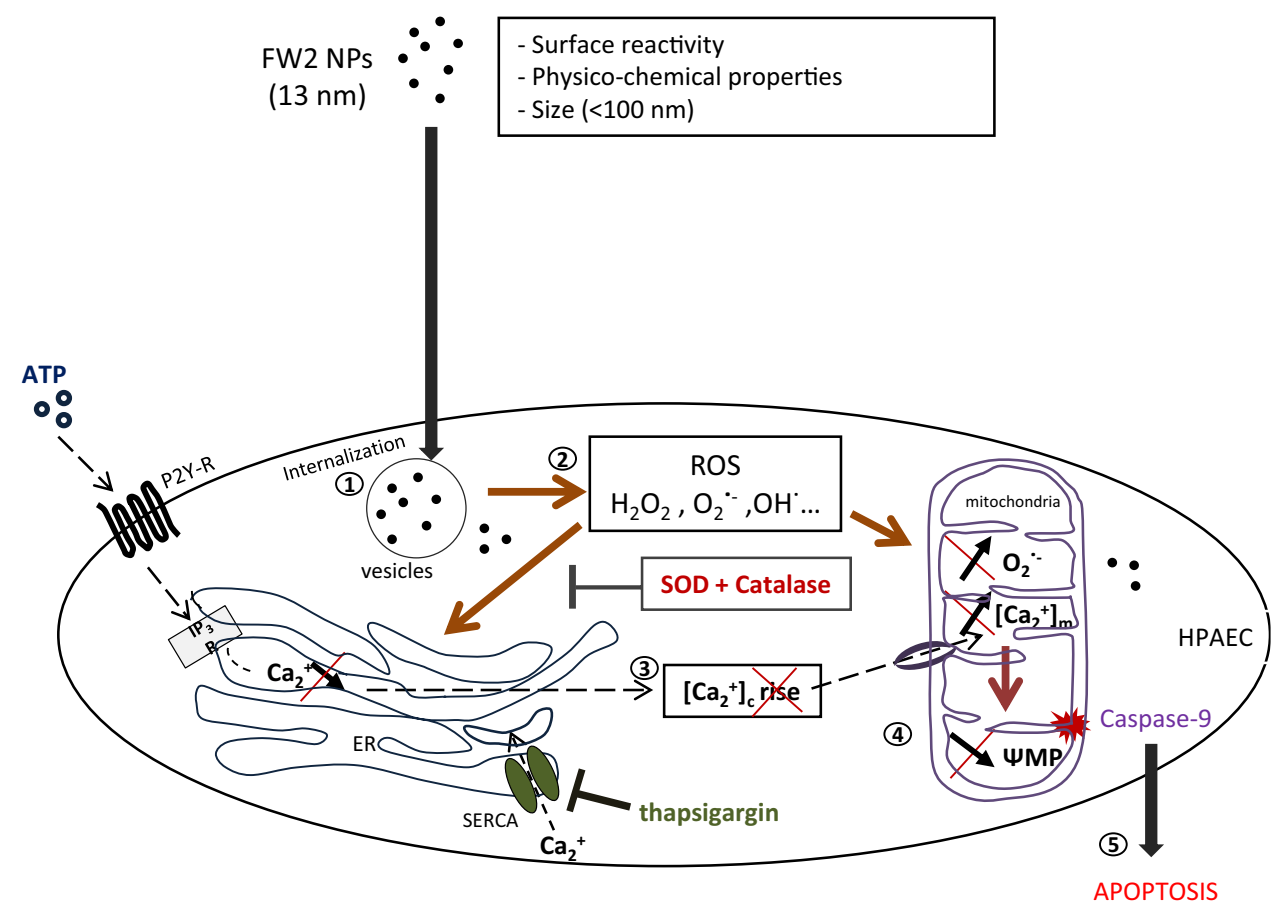

Fig. 11 Summary of hypothetical FW2 NPs oxidative stress-mediated impairment of calcium homeostasis and mitochondrial alterations. (1) FW2 NPs internalization in HPAEC. (2) FW2 NPs induce oxidative stress (ROS production). (3) Oxidative stress induces cytoplasmic $\left[\mathrm{Ca}^{2+}\right]$ rise in HPAEC mediated by ER $\left[\mathrm{Ca}^{2+}\right]$ stores release. (4) Oxidative stress induces mitochondria alterations $\left(\left[\mathrm{Ca}^{2+}\right]\right.$ rise, $\Psi$ MP dim-

Acknowledgements Juliette DEWEIRDT is supported by "Fondation pour la Recherche Médicale"-FRM PMJ20151034585.

Funding No funding.

\section{Compliance with ethical standards}

Conflict of interest The authors declare that they have no conflict of interest.

\section{References}

Bagur R, Hajnoczky G (2017) Intracellular $\mathrm{Ca}^{2+}{ }^{2+}$ sensing: its role in calcium homeostasis and signaling. Mol Cell 66:780-788. https ://doi.org/10.1016/j.molcel.2017.05.028

Bergamaschi E et al (2015) Impact and effectiveness of risk mitigation strategies on the insurability of nanomaterial production: evidences from industrial case studies. Wiley Interdiscip Rev Nanomed Nanobiotechnol 7:839-855. https://doi.org/10.1002/ wnan. 1340

Berridge MJ, Bootman MD, Roderick HL (2003) Calcium signalling: dynamics, homeostasis and remodelling. Nat Rev Mol Cell Biol 4(7):517-529. https://doi.org/10.1038/nrm1155 inution). (5) FW2 NPs induce apoptosis by intrinsic pathway (caspase-9 induction). NPs nanoparticles, ROS reactive oxygen species, $\mathrm{O}_{2}{ }^{-}$superoxide anion, $\mathrm{SOD}$ superoxide dismutase, $\mathrm{Ca}^{2+}$ calcium, $\mathrm{ER}$ endoplasmic reticulum, $A T P$ adenosine triphosphate, $I P_{3} R$ Inositol trisphosphate receptor, $\Psi M P$ mitochondrial membrane potential

Bhandary B, Marahatta A, Kim HR, Chae HJ (2012) An involvement of oxidative stress in endoplasmic reticulum stress and its associated diseases. Int J Mol Sci 14:434-456. https://doi.org/10.3390/ ijms 14010434

Billaud M, Marthan R, Savineau JP, Guibert C (2009) Vascular smooth muscle modulates endothelial control of vasoreactivity via reactive oxygen species production through myoendothelial communications. PLoS ONE 4:e6432. https://doi.org/10.1371/journ al.pone. 0006432

Boland S, Hussain S, Baeza-Squiban A (2014) Carbon black and titanium dioxide nanoparticles induce distinct molecular mechanisms of toxicity. Wiley Interdiscip Rev Nanomed Nanobiotechnol 6:641-652. https://doi.org/10.1002/wnan.1302

Borm PJ et al (2006) The potential risks of nanomaterials: a review carried out for ECETOC. Part Fibre Toxicol 3:11. https://doi. org/10.1186/1743-8977-3-11

Brown DM, Dickson C, Duncan P, Al-Attili F, Stone V (2010) Interaction between nanoparticles and cytokine proteins: impact on protein and particle functionality. Nanotechnology 21:215104. https://doi.org/10.1088/0957-4484/21/21/215104

Calderon-Garciduenas L et al (2001) Canines as sentinel species for assessing chronic exposures to air pollutants: part 1. Respiratory pathology. Toxicol Sci 61:342-355. https://doi.org/10.1093/ toxsci/61.2.342

Cao Y, Roursgaard M, Danielsen PH, Moller P, Loft S (2014) Carbon black nanoparticles promote endothelial activation and lipid accumulation in macrophages independently of 
intracellular ROS production. PLoS ONE 9:e106711. https:// doi.org/10.1371/journal.pone.0106711

Chen X, Zhong Z, Xu Z, Chen L, Wang Y (2010) 2',7'-Dichlorodihydrofluorescein as a fluorescent probe for reactive oxygen species measurement: forty years of application and controversy. Free Radic Res 44:587-604. https://doi.org/10.3109/1071576100 3709802

Choi S et al (2017) Mitochondrial calcium uniporter in Drosophila transfers calcium between the endoplasmic reticulum and mitochondria in oxidative stress-induced cell death. J Biol Chem 292:14473-14485. https://doi.org/10.1074/jbc.M116.765578

Cioffi DL (2011) Redox regulation of endothelial canonical transient receptor potential channels. Antioxid Redox Signal 15:15671582. https://doi.org/10.1089/ars.2010.3740

Davidson SM, Duchen MR (2007) Endothelial mitochondria: contributing to vascular function and disease. Circ Res 100:1128-1141. https://doi.org/10.1161/01.RES.0000261970.18328.1d

Deniaud A, Sharaf el dein O, Maillier E, Poncet D, Kroemer G, Lemaire C, Brenner C (2008) Endoplasmic reticulum stress induces calcium-dependent permeability transition, mitochondrial outer membrane permeabilization and apoptosis. Oncogene 27:285-299. https://doi.org/10.1038/sj.onc.1210638

Deweirdt J et al (2017) Involvement of oxidative stress and calcium signaling in airborne particulate matter-induced damages in human pulmonary artery endothelial cells. Toxicol In Vitro 45:340-350. https://doi.org/10.1016/j.tiv.2017.07.001

Dubes V et al (2017) Calcium signalling induced by in vitro exposure to silicium dioxide nanoparticles in rat pulmonary artery smooth muscle cells. Toxicology 375:37-47. https://doi.org/10.1016/j. tox.2016.12.002

Evangelista AM, Thompson MD, Bolotina VM, Tong X, Cohen RA (2012) Nox4- and Nox2-dependent oxidant production is required for VEGF-induced SERCA cysteine-674 S-glutathiolation and endothelial cell migration. Free Radic Biol Med 53:2327-2334. https://doi.org/10.1016/j.freeradbiomed.2012.10.546

Faisal M et al (2016) Cobalt oxide nanoparticles aggravate DNA damage and cell death in eggplant via mitochondrial swelling and NO signaling pathway. Biol Res 49:20. https://doi.org/10.1186/s4065 9-016-0080-9

Goedicke-Fritz S et al (2015) Evidence for functional and dynamic microcompartmentation of Cav-1/TRPV4/K $(\mathrm{Ca})$ in caveolae of endothelial cells. Eur J Cell Biol 94:391-400. https://doi. org/10.1016/j.ejcb.2015.06.002

Goldenberg NM, Kuebler WM (2015) Endothelial cell regulation of pulmonary vascular tone, inflammation, and coagulation. Compr Physiol 2:531-559. https://doi.org/10.1002/cphy.c140024

Gordeeva AV, Zvyagilskaya RA, Labas YA (2003) Cross-talk between reactive oxygen species and calcium in living cells. Biochem Biokhimiia 68:1077-1080. https://doi.org/10.1023/A:10263 98310003

Guibert C, Marthan R, Savineau JP (2007) Modulation of ion channels in pulmonary arterial hypertension. Curr Pharm Des 13:24432455. https://doi.org/10.2174/138161207781368585

Guo D, Bi H, Wang D, Wu Q (2013) Zinc oxide nanoparticles decrease the expression and activity of plasma membrane calcium ATPase, disrupt the intracellular calcium homeostasis in rat retinal ganglion cells. Int J Biochem Cell Biol 45:1849-1859. https://doi. org/10.1016/j.biocel.2013.06.002

Guo C et al (2015) Silica nanoparticles induce oxidative stress, inflammation, and endothelial dysfunction in vitro via activation of the MAPK/Nrf2 pathway and nuclear factor-kappaB signaling. Int J Nanomed 10:1463-1477. https://doi.org/10.2147/ijn.s76114

Helfenstein $\mathrm{M}$ et al (2008) Effects of combustion-derived ultrafine particles and manufactured nanoparticles on heart cells in vitro. Toxicology 253:70-78. https://doi.org/10.1016/j.tox.2008.08.018
Hussain S et al (2009) Oxidative stress and proinflammatory effects of carbon black and titanium dioxide nanoparticles: role of particle surface area and internalized amount. Toxicology 260:142-149. https://doi.org/10.1016/j.tox.2009.04.001

Itoh $Y$ et al (2006) Reactive oxygen species generated by mitochondrial injury in human brain microvessel endothelial cells. Clin Hemorheol Microcirc 34(1-2):163-168

Janzen J (1979) The refractive index of colloidal carbon. J Colloid Interface Sci 69:436-447. https://doi.org/10.1016/00219797(79)90133-4

Lai N, Lu W, Wang J (2015) $\mathrm{Ca}\left({ }^{2+}\right)$ and ion channels in hypoxia-mediated pulmonary hypertension. Int J Clin Exp Pathol 8:1081-1092

L'Azou B et al (2008) In vitro effects of nanoparticles on renal cells. Part Fibre Toxicol 5:22. https://doi.org/10.1186/1743-8977-5-22

Ma JH et al (2017) Comparative proteomic analysis of the mitochondria-associated ER membrane (MAM) in a long-term type 2 diabetic rodent model. Sci Rep 7:2062. https://doi.org/10.1038/s4159 8-017-02213-1

Marchi S et al (2018) Mitochondrial and endoplasmic reticulum calcium homeostasis and cell death. Cell Calcium 69:62-72. https:// doi.org/10.1016/j.ceca.2017.05.003

Miller MR et al (2017) Inhaled nanoparticles accumulate at sites of vascular disease. ACS Nano 11:4542-4552. https://doi.org/10.1021/ acsnano.6b08551

Monteiller C, Tran L, MacNee W, Faux S, Jones A, Miller B, Donaldson K (2007) The pro-inflammatory effects of low-toxicity low-solubility particles, nanoparticles and fine particles, on epithelial cells in vitro: the role of surface area. Occup Environ Med 64:609-615. https://doi.org/10.1136/oem.2005.024802

Mossman BT, Borm PJ, Castranova V, Costa DL, Donaldson K, Kleeberger SR (2007) Mechanisms of action of inhaled fibers, particles and nanoparticles in lung and cardiovascular diseases. Part Fibre Toxicol 4:4. https://doi.org/10.1186/1743-8977-4-4

Nemmar A et al (2002) Passage of inhaled particles into the blood circulation in humans. Circulation 105:411-414. https://doi. org/10.1161/hc0402.104118

Niwa Y, Hiura Y, Murayama T, Yokode M, Iwai N (2007) Nano-sized carbon black exposure exacerbates atherosclerosis in LDL-receptor knockout mice. Circ J 71:1157-1161. https://doi.org/10.1253/ circj. 71.1157

Oshima $\mathrm{T}$ et al (2005) Beneficial effect of T-type calcium channel blockers on endothelial function in patients with essential hypertension. Hypertens Res 28:889-894. https://doi.org/10.1291/hypre s.28.889

Quintero M, Colombo SL, Godfrey A, Moncada S (2006) Mitochondria as signaling organelles in the vascular endothelium. Proc Natl Acad Sci USA 103:5379-5384. https://doi.org/10.1073/ pnas.0601026103

Schulte PA, Schubauer-Berigan MK, Mayweather C, Geraci CL, Zumwalde R, McKernan JL (2009) Issues in the development of epidemiologic studies of workers exposed to engineered nanoparticles. J Occup Environ Med 51:323-335. https://doi.org/10.1097/ JOM.0b013e3181990c2c

Sharov VS, Schoneich C (2000) Diastereoselective protein methionine oxidation by reactive oxygen species and diastereoselective repair by methionine sulfoxide reductase. Free Radic Biol Med 29:986-994. https://doi.org/10.1016/s0891-5849(00)00400-7

Shen Y, Wu L, Qin D, Xia Y, Zhou Z, Zhang X, Wu X (2018) Carbon black suppresses the osteogenesis of mesenchymal stem cells: the role of mitochondria. Part Fibre Toxicol 15:16. https://doi. org/10.1186/s12989-018-0253-5

Simon $M$ et al (2017) In situ quantification of diverse titanium dioxide nanoparticles unveils selective endoplasmic reticulum stressdependent toxicity. Nanotoxicology 11:134-145. https://doi. org/10.1080/17435390.2017.1278803 
Touyz RM (2005) Reactive oxygen species as mediators of calcium signaling by angiotensin II: implications in vascular physiology and pathophysiology. Antioxid Redox Signal 7(9-10):1302-1314. https://doi.org/10.1089/ars.2005.7.1302

van der Wijk T, Overvoorde J, den Hertog J (2004) $\mathrm{H}_{2} \mathrm{O}_{2}$-induced intermolecular disulfide bond formation between receptor proteintyrosine phosphatases. J Biol Chem 279:44355-44361. https://doi. org/10.1074/jbc.M407483200

Vanhoutte PM, Shimokawa H, Feletou M, Tang EH (2017) Endothelial dysfunction and vascular disease-a 30th anniversary update. Acta Physiol (Oxford, England) 219:22-96. https://doi. org/10.1111/apha.12646

Vesterdal LK, Folkmann JK, Jacobsen NR, Sheykhzade M, Wallin H, Loft S, Moller P (2010) Pulmonary exposure to carbon black nanoparticles and vascular effects. Part Fibre Toxicol 7:33. https ://doi.org/10.1186/1743-8977-7-33

Vesterdal LK et al (2012) Carbon black nanoparticles and vascular dysfunction in cultured endothelial cells and artery segments. Toxicol Lett 214:19-26. https://doi.org/10.1016/j.toxlet.2012.07.022

Vishnu $\mathrm{N}$ et al (2014) ATP increases within the lumen of the endoplasmic reticulum upon intracellular $\mathrm{Ca} 2+$ release. Mol Biol Cell 25(3):368-379. https://doi.org/10.1091/mbc.E13-07-0433

Wang H, Joseph JA (1999) Quantifying cellular oxidative stress by dichlorofluorescein assay using microplate reader. Free Radic Biol Med 27:612-616. https://doi.org/10.1016/s0891-5849(99)00107-0

Watson AY, Valberg PA (2001) Carbon black and soot: two different substances. AIHAJ J Sci Occup Environ Health Saf 62:218-228. https://doi.org/10.1080/15298660108984625

Westermann B (2010) Mitochondrial fusion and fission in cell life and death. Nat Rev Mol Cell Biol 11:872-884. https://doi. org/10.1038/nrm3013

Wu T, Tang M (2018) Review of the effects of manufactured nanoparticles on mammalian target organs. J Appl Toxicol JAT 38:25-40. https://doi.org/10.1002/jat.3499
Yamawaki H, Iwai N (2006) Mechanisms underlying nano-sized airpollution-mediated progression of atherosclerosis: carbon black causes cytotoxic injury/inflammation and inhibits cell growth in vascular endothelial cells. Circ J 70:129-140. https://doi. org/10.1253/circj.70.129

Yan J et al (2017) Carbon black aggregates cause endothelial dysfunction by activating ROCK. J Hazard Mater 338:66-75. https://doi. org/10.1016/j.jhazmat.2017.05.025

$\mathrm{Yu} \mathrm{KN}$ et al (2015) Titanium dioxide nanoparticles induce endoplasmic reticulum stress-mediated autophagic cell death via mitochondriaassociated endoplasmic reticulum membrane disruption in normal lung cells. PLoS ONE 10:e0131208. https://doi.org/10.1371/journ al.pone. 0131208

Zamponi N, Zamponi E, Cannas SA, Billoni OV, Helguera PR, Chialvo DR (2018) Mitochondrial network complexity emerges from fission/fusion dynamics. Sci Rep 8:363. https://doi.org/10.1038/ s41598-017-18351-5

Zhang DX, Gutterman DD (2007) Mitochondrial reactive oxygen species-mediated signaling in endothelial cells. Am J Physiol Heart Circ Physiol 292:H2023-2031. https://doi.org/10.1152/ ajpheart.01283.2006

Zhang R, Piao MJ, Kim KC, Kim AD, Choi JY, Choi J, Hyun JW (2012) Endoplasmic reticulum stress signaling is involved in silver nanoparticles-induced apoptosis. Int J Biochem Cell Biol 44:224-232. https://doi.org/10.1016/j.biocel.2011.10.019

Publisher's Note Springer Nature remains neutral with regard to jurisdictional claims in published maps and institutional affiliations. 